\title{
ЦИФРОВАЯ ПЛАТФОРМА КАК НОВОЕ ПРАВОВОЕ ЯВЛЕНИЕ
}

\author{
А. В. Габов \\ Член-корреспондент РАН, главный научный сотрудник \\ Институт государства и права Российской академии наук \\ 119019, Россия, г. Москва, ул. Знаменка, 10 \\ Научный руководитель юридического института \\ Белгородский государственный \\ национальный исследовательский университет \\ 308015, Россия, г. Белгород, ул. Победы, 85 \\ E-mail: Gabov@bsu.edu.ru
}

Аннотация. Рассматривается такое новое правовое явление, как цифровая платформа. Понятие «платформа» встречается в нормативных актах как СССР, так и Российской Федерации. Однако долгое время - только применительно к обозначению части инфраструктуры железнодорожного транспорта, а также для описания специфики ответственности в морском праве. И только в начале 2000-х гг. мы видим новое использование этого понятия для целей описания электронного взаимодействия в рамках т.н. «электронного правительства». С началом процесса создания нормативного обеспечения цифровой экономики мы видим массированное использование понятие «платформа» в документах политико-правового характера и нормативных актах. При этом автор отмечает бессистемность использования слова «Платформа». Показаны примеры использования понятия «цифровая платформа», а также виды платформ и их классификации. Автор оценивает влияние платформизации экономики на право.

Ключевые слова: платформа; технологическая платформа; научная платформа; электронное правительство; цифровая экономика; цифровая платформа; финансовая платформа; инвестиционная платформа; платформизация экономики; платформенное право; платформизация правосудия

\section{(C) Габов А. В., 2021}

\footnotetext{
${ }^{1}$ Основные положения данного исследования были изложены автором в одноименном докладе, сделанном в ходе Четвертой международной научно-практической конференции «Бачиловские чтения» (Москва, Институт государства и права РАН, 5 февр. 2021 г.).
} 


\title{
DIGITAL PLATFORM AS A NEW LEGAL PHENOMENON
}

\author{
A. V. Gabov
}

Institute of state and law of the Russian Academy of Sciences

10, Znamenka st., Russia, Moscow, 119019

Belgorod State University

85, Pobedy st., Belgorod, Russia, 308015

E-mail: Gabov@bsu.edu.ru

Annotation. The article deals with such a new legal phenomenon as a digital platform. The concept of «platform» was used in the normative acts of the USSR, and it is also used in the normative acts of the Russian Federation. However, for a long time only in relation to the designation of part of the railway transport infrastructure, as well as to describe the specifics of liability in the law of the sea. It is only in the early 2000s that we see a new use of this concept for the purpose of describing electronic interaction within the framework of the so-called «e-government». With the beginning of the process of creating regulatory support for the digital economy, we see a massive use of the concept of "platform» in policy documents and regulations. At the same time, the author notes the unsystematic use of the word «platform». Examples of using the concept of a «digital platform» are shown; types of platforms and their classifications are shown. The author assesses the impact of economic platformization on the law.

Key words: platform; technology platform; scientific platform; egovernment; digital economy; digital platform; financial platform; investment platform; platformization of the economy; platform law; platforming justice.

«Платформа» - полисемантичный термин:

от железных дорог к электронному правительству и далее везде...

1. Слово «платформа» французского происхождения ${ }^{1}$ и в словарях русского языка имеет несколько объяснений. Чаще всего это объяснение технического характера - возвышение, площадка для посадки пассажиров, погрузки багажа; небольшая железнодорожная станция; открытый железнодорожный вагон с низкими бортами для перевозки

1 «..фр. plate-form. In plat - плоский + forme- форма...» (см.: Потапов А. Д. Инженерно-геологический словарь / А.Д. Потапов, И.Л. Ревелис, С.Н. Чернышов. М., ИНФРА-М, 2020. C. 215). 
грузов; утолщенная подошва ; в специальных (технических) словарях под платформой понимают буровую установку на колесном, гусеничном ходу с манипуляторами и автоматически подающимися бурильными молотками для работ на водной акватории ${ }^{2}$. Однако технические объяснения этим не ограничиваются; как показывает изучение диссертационных исследований ${ }^{3}$ по различным техническим областям наук ${ }^{4}$, слово «платформа» активно используется для обозначения компьютерной программы или совокупности таких программ, а также для обозначения различного рода устройств, а именно: «робототехническая программная платформа», "локомоционная мобильная платформа», «мобильная приборная платформа», «кластерная платформа», «платформа распределенных параллельных вычислений», «гибридная вычислительная платформа» и т. д.

${ }^{1}$ См.: Ожегов С. И., Шведова Н. Ю. Толковый словарь русского языка: 80000 слов и фразеологических выражений. 2-е изд., испр. и доп. М.: АЗЪ, 1995. С. 522.

2 См.: Рашев В.Г. Искусственные сооружения железных и автомобильных дорог: Иллюстрированный словарь: около 2500 слов. СПб.: Политехника, 2008. С. 226.

3 См.: Боровик А.И. Компонентно-ориентированная программная платформа для автономных необитаемых подводных аппаратов: дис. ... канд. тех. наук. Владивосток, 2018. 177 с.; Сорокин А. П. Методы разработки модулей аппаратных вычислительных платформ для обработки сложноструктурируемых изображений: дис. ... канд. техн. наук. М., 2018. 169 с.; Грешняков П. И. Повышение энергетической эффективности мехатронной системы управления движением робота-тренажёра вождения на базе платформы Стюарта с многопозиционным цифровым управлением электропневматическими следящими приводами на дискретных клапанах: дис. ... канд. техн. наук. Самара, 2019. 193 с.; Классен Р. К. Консервативные СУБД класса BIGDATA с регулярным планом обработки запросов на кластерной платформе: автореф. дис. ... канд. техн. наук. Казань, 2019. 26 с.; Кленов А. И. Динамический синтез и анализ механизма, реализующего движение локомоционной мобильной платформы в жидкости: дис. ... канд. техн. наук. Ижевск, 2019.137 с.; Коржавина А. С. Методы и алгоритмы модулярной арифметики для массовой обработки сверхдлинных чисел на гибридных вычислительных платформах: автореф. дис. ... канд. техн. наук. Пенза, 2019. 23 с.; Поляков Р. Ю. Мобильная приборная платформа для системы экологического мониторинга загрязнения токсичными газами атмосферного воздуха: дис. ... канд. техн. наук. Курск, 2019. 165 с.; Пролетарская В. А. Метод выполнения запросов к хранилищу данных на платформе распределённой параллельной обработки данных: дис. ... канд. техн. наук. М., 2020. 143 с.; Пыстогов С. В. СУБД полнообъектных картографических сцен с ассоциативной защитой на кластерной платформе: дис. ... канд. техн. наук. Казань, 2019. 144 с. и ряд других диссертационных исследований.

${ }^{4}$ Анализ диссертационных исследований показывает, что в рамках действующей номенклатуры научных специальностей различные аспекты платформ исследуются в рамках следующих специальностей: «05.02.05 - Роботы, мехатроника и робототехнические системы»; «05.02.18 - Теория механизмов и машин»; «05.11.03 - Приборы навигации»; «05.13.05 - Элементы и устройства вычислительной техники и систем управления»; «05.13.11 - Математическое и программное обеспечение вычислительных машин, комплексов и компьютерных сетей»; «05.13.15 - Вычислительные машины, комплексы и компьютерные сети». 
Слово «платформа» используется в политическом словаре как (упрощенно) политическая программа партии, общественной группировки ${ }^{1}$.

Используется это слово в геологии и географии, где о платформе говорят как о части материковой земной коры².

Таким образом, хорошо видно, что слово «платформа» имеет множество значений и используется для обозначения очень разных явлений.

В отечественном праве мы видим использование этого слова традиционно (еще со времен СССР) в нормативных актах, регулирующих вопросы организации железнодорожного транспорта; к примеру, в статье 10 Устава железных дорог Союза ССР, утвержденного постановлением Совмина СССР от 6 апреля 1964 г. № 270, использовалось понятие «специальные платформы», которые, как отмечается в комментариях, относились к числу сооружений и устройств для осуществления технических и грузовых операций․

В российском законодательстве, регулирующем организацию железнодорожного транспорта (перевозок), соответствующих ГОСТах, стратегиях также используется понятие «платформа». В частности, в них можно встретить ${ }^{4}$ указание: на собственно «платформу» (без использования этого слова с каким-либо прилагательным, придающим качество); «железнодорожную платформу»; «пассажирскую плат-

${ }^{1}$ См.: Ожегов С. И., Шведова Н. Ю. Указ. соч. С. 522.

2 К примеру, можно привести такое определение из инженерно-геологического словаря: «Платформа... - одна из главных глубинных структур земной коры, характеризующаяся малой интенсивностью тектонических движений и плоским рельефом. П. имеют двухъярусное строение: нижний ярус - фундамент П. - образуют комплексы метаморфических и магматических горных пород, имеющих складки и разрывы; верхний ярус (платформенный чехол, осадочный чехол) сложен субгоризонтально залегающими преимущественно осадочными и отчасти вулканогенными толщами. В пределах П. выделяются щиты, где складчатый фундамент выступает на поверхность, и плиmы, в которых фундамент погружен на глубину. П. подразделяются на древние с фундаментом докембрийского возраста (напр., Сибирская) и молодые с фундаментом палеозойского и мезозойского возраста (напр., равнинные территории Западной Сибири)» (см.: Потапов А.Д. Указ. соч. С. 215; Рашев В. Г. Указ. соч. С. 225).

${ }^{3}$ См.: Комментарий к Уставу железных дорог СССР / под ред. Г. Б. Астановского. М.: Юридическая литература, 1986. С. 30-31.

${ }^{4}$ См.: ст. 80, 80.1 Федерального закона от 10 января 2003 г. № 18-ФЗ «Устав железнодорожного транспорта Российской Федерации», приложения, утвержденные постановлением Правительства РФ от 6 февраля 2004 г. № 57 «Об ограниченных в обороте объектах имущества открытого акционерного общества "Российские железные дороги"», ГОСТ Р 55056-2012 Транспорт железнодорожный. Основные понятия. Термины и определения; Стратегия развития морской портовой инфраструктуры в России до 2030 г., утв. в 2012 г., одобренная на совещании членов Морской коллегии при Правительстве Российской Федерации 28 сентября 2012 г. и др. документы. 
форму»; «воинскую платформу»; «регулируемую горизонтальную или наклонную платформу»; «низкую платформу»; «подъемную платформу»; «фиттинговую платформу».

Если упрощенно, то в таком контексте под платформой понимается часть инфраструктуры - место (сооружение и/или устройство), с помощью которого осуществляется обслуживание пассажиров и погрузочно-разгрузочных работ или (реже) - вид подвижного состава (фиттинговые платформы).

Следующая часть нормативного материала, где используется понятие «платформа», - это документы, регулирующие добычу природных ресурсов (нефти и газа) в море; здесь используются ${ }^{1}$ понятия: «морская платформа»; "стационарная платформа»; «плавучая платформа»; «плавучая (подвижная) буровая установка (платформа)»; «морская плавучая (передвижная) платформа»; «платформа гравитационного типа»; «ледовая платформа»; «буровая платформа»; «платформы для добычи нефти и газа на шельфе»; «добычная платформа»; "разведывательная платформа» и т. д.

Для этой сферы понятие «платформа» может быть объяснено (упрощенно) следующим образом: плавучее (передвижное) или стационарное сооружение, предназначенное для размещения оборудования и людей, занимающихся добычей определенных природных ресурсов (нефти и газа).

В законодательстве есть понятие «подъемная платформа для инвалидов»²: грузоподъемная машина с вертикальным (угол перемеще-

${ }^{1}$ См.: Международная конвенция по предотвращению загрязнения с судов 1973 г., изм. Протоколом 1978 г. к ней (МАРПОЛ 73/78); ст. 16 Федерального закона от 31 июля 1998 г. № 155-Ф3 «0 внутренних морских водах, территориальном море и прилежащей зоне Российской Федерации»; ГОСТ Р 55311-2012 Нефтяная и газовая промышленность. Сооружения нефтегазопромысловые морские. Термины и определения; Стратегия социально-экономического развития Северо-Западного федерального округа на период до 2020 г., утв. распоряжением Правительства РФ от 18 ноября 2011 г. № 2074-р; Морская доктрина Российской Федерации, утв. Президентом РФ 26 июля 2015 г.; Стратегия развития судостроительной промышленности на период до 2035 г., утв. распоряжением Правительства РФ от 28 октября 2019 г. № 2553-р; Энергетическая стратегия Российской Федерации на период до 2035 г., утв. распоряжением Правительства РФ от 9 июня 2020 г. № 1523-р; Основа государственной политики Российской Федерации в Арктике на период до 2035 г., утв. Указом Президента РФ от 5 марта 2020 г. № 164 и др.

2 См.: ст. 55.24 Градостроительного кодекса РФ; Приложение 1 к Федеральному закону от 21 июля 1997 г. № 116-Ф3 «0 промышленной безопасности опасных производственных объектов»; п. 3 Правил организации безопасного использования и содержания лифтов, подъемных платформ для инвалидов, пассажирских конвейеров (движущихся пешеходных дорожек) и эскалаторов, за исключением эскалаторов в метрополитенах, утв. постановлением Правительства Российской Федерации от 24 июня 2017 г. № 743 и др. 
ния платформы не более 15 градусов от вертикали) или наклонным (угол перемещения платформы к горизонтали не более 75 градусов) перемещением для подъема и спуска пассажиров из числа инвалидов и других маломобильных групп населения, размещающихся на грузонесущем устройстве.

Понятие «платформа» («плавающая платформа», «рабочая платформа») используется в нормативных документах по техническому регулированию ${ }^{1}$. Контекст использования этих понятий показывает, что речь идет о части оборудования, площадке для размещения людей и имущества (механизмов).

В ряде нормативных актов встречается понятие «космическая платформа» ${ }^{2}$.

При всем многообразии платформ различных видов, перечисленных выше ${ }^{3}$, как и во всех перечисленных случаях использования этого понятия в нормативных документах, есть общие черты:

- во-первых, с философской точки зрения, платформа - это основа для чего-либо (нахождения на ней людей и имущества и/или деятельности на ней таких людей с использованием этого имущества);

- во-вторых, любая платформа - это сооружение и/или специальное оборудование, т. е. перед нами реальные, физически осязаемые предметы;

- в-третьих, с точки зрения функционального использования, в виде платформы перед нами существующая в ограниченном пространстве локальная площуадка (место) для размещения людей, оборудования, грузов и иного имущества;

- в-четвертых, такая площадка (место) используется для выполнения различных действий по перемещению людей и движимого имущества (грузов) или для осуществления на ней определенной деятельности (морская платформа).

Некоторыми особенностями обладают понятие «автомобильная платформа», а также различные виды таких платформ - «глобальная

${ }^{1}$ См.: решение Комиссии Таможенного союза от 9 декабря 2011 г. № 877 «0 принятии технического регламента Таможенного союза “О безопасности колесных транспортных средств"»; решение Совета Евразийской экономической комиссии от 18 октября 2016 г. № 114 «0 техническом регламенте Евразийского Экономического Союза “О безопасности аттракционов"»; Требования к техническому состоянию и эксплуатации аттракционов, утв. постановлением Правительства РФ от 20 декабря 2019 г. № 1732 .

${ }^{2}$ К примеру, см.: Список товаров и технологий двойного назначения, которые могут быть использованы при создании вооружений и военной техники и в отношении которых осуществляется экспортный контроль, утв. указом Президента РФ от 17 декабря 2011 г. № 1661.

3 Отметим, что ими примеры использования в нормативных документах понятия «платформа» не исчерпываются. 
платформа», «российская платформа», «локальная платформа», «единая модульная платформа» и т. д., которые упоминаются в документах стратегического планирования, посвященных вопросам развития автомобильной промышленности и экспорта продукции указанной промышленности, - Стратегии развития автомобильной промышленности Российской Федерации на период до 2025 года ${ }^{1}$ и Стратегии развития экспорта продукции автомобильной промышленности в Российской Федерации на период до 2025 года ${ }^{2}$, а также ряде иных документов (см.: Государственная программа Российской Федерации «Развитие промышленности и повышение ее конкурентоспособности» ${ }^{3}$ ).

В Стратегии развития автомобильной промышленности Российской Федерации на период до 2025 года дается следующее определение автомобильной платформы: «компоновочная схема автотранспортного средства, объединяющая конструкторско-технологические решения и агрегатную часть, используемая как основа для создания моделей или модельных рядов...».

Здесь есть отдаленная схожесть с признаками платформы, выделенными выше (платформа как основа), однако видна и существенная разница: платформа здесь - это, скорее, воплощенная (материализованная) конструкторская идея, которая является основой для появления новой модели транспортного средства.

2. В 2000-х гг. понятие «платформа» стало входить в программные документы, концепции, стратегии, устанавливающие цели и задачи развития электронного взаимодействия участников различных правоотношений.

В первой программе «Электронная Россия», утвержденной в 2002 г. $^{4}$, это понятие отсутствовало; в документе использовалась сложившаяся к тому времени нормативная терминология - «взаимодействие на основе использования современных ИКТ», «информационная и телекоммуникационная инфраструктура» и проч. Также традиционная терминология использовалась и в Стратегии развития информационного общества в Российской Федерации, утвержденной в начале 2008 г. ${ }^{5}$ В Стратегии слово «платформа» не встречается, хотя по своему названию и предмету перед нами документ, определяющий,

1 Утверждена распоряжением Правительства РФ от 28 апреля 2018 г. № 831-р.

2 Утверждена распоряжением Правительства РФ от 31 августа 2017 г. № 1877-р.

3 Утверждена постановлением Правительства РФ от 15 апреля 2014 г. № 328.

${ }^{4}$ См.: Федеральная целевая программа «Электронная России (2002-2010 годы)», утв. постановлением Правительства РФ от 28 января 2002 г. № 65.

5 Утверждена Президентом Российской Федерации 7 февраля 2008 г. № Пр-212. 
среди прочего, политико-правовые установки, а также терминологию, которую в дальнейшем будут использовать нормативные акты.

Однако в том же 2008 году мы видим появление документов, в которых слово «платформа» начинает использоваться для описания различных аспектов электронного взаимодействия участников различных правоотношений. К примеру, в Концепции формирования в Российской Федерации электронного правительства до 2010 года, утвержденной в 2008 г. $^{2}$, мы встречаем понятие «программно-annapamная платформа» (во множественном числе), которое, судя по контексту, обозначало оборудование для дистанционного взаимодействия ${ }^{3}$.

Значительное расширение использования слова «платформа» мы видим в новой редакции программы «Электронная Россия», утвержденной в 2009 г. ; в ней понятие платформа использовано (в первой редакции) 38 раз, в основном с прилагательным «технологическая», чаще всего образуя следующий новый феномен - «технологическая платформа инфраструктуры электронного правительства»; такая платформа должна была стать в первую очередь базой для межведом-

1 Какова была теоретическая основа перехода к использованию новой правовой терминологии, не вполне понятно. По крайней мере изучение исследований по информационному праву ясности в вопрос не вносит (см.: Теоретические проблемы информационного права. М.: Институт государства и права РАН, 2006. 291 с.; Информационное право и становление основ гражданского общества в России. Материалы теоретического семинара по информационному праву 2007 г. / под ред. И.Л. Бачило. М.: Институт государства и права РАН, 2008. 277 с.; Условия реализации прав граждан и организаций на основе информационных технологий. М.: Институт государства и права РАН. ИПО «У Никитских ворот», 2010. 248 с.; Информационное право: учебник / Л.Л. Попов, Ю.И. Мигачев, С.В. Тихомиров. М.: Норма: Инфра-М, 2010. 496 с.; Информационное общество и социальное государство: сб. науч. работ. М.: Институт государства и права РАН; ИПО «У Никитских ворот», 2011. 248 с.; Право цифровой администрации в России и во Франции: сб. науч. материалов российско-французской междунар. конф. 27-28 февраля 2013 г. М.: Институт государства и права РАН; Изд-во «Канон+» РООИ «Реабилитация», 2014. 178 с. и др. работы).

Скорее всего, использование слова «платформа» в правовых текстах - это перенос технического (из сферы программирования) вокабуляра в сферу права, на который правовая наука не обратила внимания, или ее представители (в части информационного права) посчитали соответствующее заимствование вполне закономерным, поскольку перечень понятий этого научного направления в тот период только складывался, и во многом за счет заимствования технических терминов (к примеру, см.: Семилетов С.И. Правовые проблемы организации электронного оборота документов в государственном управлении // Теоретические проблемы информационного права. М.: Институт государства и права РАН, 2006. С. 162-166).

2 Утверждена распоряжением Правительства РФ от 6 мая 2008 г. № 632-р.

${ }^{3}$ Приведем следующий фрагмент: «...электронные платежи осуществляются пользователями с различных программно-аппаратных платформ, включая мобильные электронные устройства...».

4 Утверждена постановлением Правительства РФ от 10 сентября 2009 г. № 721. 
ственного электронного документооборота и предоставления государственных услуг в электронном виде.

В Основных направлениях деятельности Правительства Российской Федерации на период до 2012 года, утвержденных в 2008 г. (в редакции 2009 г.) ${ }^{1}$, указывалось на необходимость создания «единой универсальной информационно-коммуникационной платформы», обеспечивающей получение на территории страны информации в разных форматах, в том числе в интерактивном режиме, с технологической основой такой платформы в виде сети высокоскоростных каналов магистральной связи, абонентских линий широкополосного доступа (включая мобильный доступ) к сетям электросвязи.

В Государственной программе Российской Федерации «Информационное общество (2011-2020 годы)» 2010 г. $^{2}$ слово «платформа» использовано (в первой редакции) 29 раз: один раз в политико-правовом контексте ${ }^{3}$, второй - для указания на достижения в реализации программы «Электронная России»4, а во всех остальных случаях - в интересующем нас контексте (описание электронного взаимодействия).

В частности, в Государственной программе Российской Федерации «Информационное общество (2011-2020 годы)» 2010 г. встречается указание на «программно-аппаратные платформы» (как оборудование, используемое для электронного взаимодействия), а также есть указания на следующие виды платформ:

- «единая информационно-аналитическая платформа»;

- «геоинформационная платформа»;

- «национальна платформа “облачных вычислений”, в том числе «интернет-платформа "облачных вычислений”;;

- «национальная программная платформа»;

- «централизованная сервисная платформа с использованием гибкого программного коммутатора»;

- «национальная информационно-коммуникационная платформа для распространения цифрового контента», в том числе "многофункциональная платформа для загрузки, обработки и распространения цифрового контента»;

1 Утверждена распоряжением Правительства РФ от 17 ноября 2008 г. № 1663-р.

2 Утверждена распоряжением Правительства РФ от 20 октября 2010 г. № 1815-р.

3 Приведем следующий фрагмент: «... создание информационного общества рассматривается как платформа для решения задач более высокого уровня - модернизации экономики и общественных отношений, обеспечения конституционных прав граждан и высвобождения ресурсов для личностного развития...».

${ }^{4}$ Приведем следующий фрагмент: «...разработан системный проект по созданию технологической платформы и инфраструктуры электронного правительства...». 
- «технологическая платформа, обеспечивающая создание, функционирование и техническую поддержку федеральных, региональных и муниципальных сайтов в сети "Интернет"»;

- «единая коммуникационная платформа»;

- «аппаратная платформа».

При всем многообразии упоминаемых в документе видов платформ отсутствуют:

определение понятия «платформа» и объяснение того, почему и в каком контексте оно используется;

1) определение абсолютного большинства различных платформ. Соответствующие определения (причем исключительно в виде пояснений в скобках) можно найти только в двух случаях:

- в части «национальной программной платформы» имеется такое пояснение: «комплекс отечественных программных решений - модулей, построенных на базе единых технологий, позволяющих осуществлять разработку новых программных продуктов методом компоновки и настройки уже готовых модулей, а также разработку новых модулей»;

- в части «технологической платформы, обеспечивающей создание, функционирование и техническую поддержку федеральных, региональных и муниципальных сайтов в сети «Интернет» дано такое пояснение: «конструктор сайтов, позволяющий создать сайт федерального, регионального или муниципального органа власти».

По существу, в обоих случаях платформа - это то, что в ГК РФ (ст. 1225 ГК РФ) охватывается таким результатом интеллектуальной деятельности, как программа для электронных вычислительных машин (программы для ЭВМ). Учитывая, что ранее в этой программе говорилось о программно-аппаратных платформах как оборудовании, то, по существу, перед нами пример полисемантичного использования слова «платформа» уже и для новой сферы - дистанционного электронного взаимодействия.

В похожей логике написан и другой документ - Государственная программа Российской Федерации «Информационное общество (2011-2020 годы)» 2014 года. В ней слово «платформа» встречается восемь раз - один раз в контексте политическом ${ }^{2}$, в остальных случаях - для описания платформ различных видов, перечень которых частично совпадает с предыдущей программой, а частично является новым:

- «национальная программная платформа»,

1 Утверждена постановлением Правительства РФ от 15 апреля 2014 г. № 313.

2 «Программа должна обеспечить создание платформы для решения задачи по модернизации экономики и общественных отношений...». 
- «национальная платформа предоставления сервисов по удаленной обработке и хранению данных»;

- «национальная информационно-коммуникационная платформа цифрового контента»;

- «программно-аппаратная платформа».

3. Значительное число концептуальных программных документов и стратегий в доцифровой период используют понятие «технологическая платформа», которое не является отечественным изобретением, а представляет собой заимствование из европейского опыта.

Понятие «технологическая платформа» мы находим в Концепции долгосрочного социально-экономического развития Российской Федерации на период до 2020 года ${ }^{1}$, утвержденной в ноябре 2008 г. В ней слово «платформа» использовано три раза и в разных контекстах помимо интересующего нас контекста, также в политическом ${ }^{2}$ и геологическом ${ }^{3}$. «Технологическая платформа» в этом документе обозначена как средство (хотя это слово в документе не использовалось) для обеспечения взаимодействия бизнеса и науки по определению и развитию перспективных направлений.

Понятие «технологическая платформа» впоследствии войдет во множество документов ${ }^{4}$ и будет иметь несколько определений.

К примеру, в Стратегии развития морской портовой инфраструктуры в России до 2030 г., утвержденной в 2012 г. ${ }^{5}$, технологической платформе дается такое определение: «объединение компаний по функциональному признаку с целью организации и проведения деятель-

\footnotetext{
1 Утверждена распоряжением Правительства РФ от 17 ноября 2008 г. № 1662-р.
}

2 Понятие «платформа» использовано для обозначения «высокопроизводительных отраслей новой экономики», которые призваны «стать платформой инновационной экономики южных регионов».

${ }^{3}$ Приведем следующий фрагмент: «...разработка нефтегазовых месторождений юга Сибирской платформы и континентального шельфа Российской Федерации...».

4 Также см.: Стратегия социально-экономического развития Центрального федерального округа до 2020 года, утв. распоряжением Правительства РФ от 6 сентября 2011 г. № 1540-p; Программа фундаментальных научных исследований государственных академий наук на 2013-2020 годы, утв. распоряжением Правительства РФ от 3 декабря 2012 г. № 2237-р; Основные направления деятельности Правительства Российской Федерации на период до 2018 года, утв. председателем Правительства РФ 31 января 2013 г., а также указанные направления в новой редакции, утв. председателем Правительства РФ 14 мая 2015 г. № 2914п-П13; Стратегия развития медицинской науки в Российской Федерации на период до 2025 года, утв. распоряжением Правительства РФ от 28 декабря 2012 г. № 2580-р; Концепция федеральной целевой программы «Научные и научно-педагогические кадры инновационной России» на 2014-2020 годы, утв. распоряжением Правительства РФ от 8 мая 2013 г. № 760-р, и др. документы.

5 Одобрена на совещании членов Морской коллегии при Правительстве Российской Федерации 28 сентября 2012 года. 
ности по подготовке, проведению и использованию результатов долгосрочных научно-технических прогнозов».

Более общее, но похожее определение находим в Стратегии социально-экономического развития Центрального федерального округа до 2020 года ${ }^{1}:$ «организационная форма реализации государственночастного партнерства и инструмент осуществления научно-технической и инновационной политики в приоритетных направлениях технологической модернизации региональной экономики».

В то же время в Стратегии инновационного развития Российской Федерации на период до 2020 года $^{2}$, принятой в 2011 г., понятие «технологическая платформа» (употребляется в начальной редакции документа 24 раза) определено следующим образом: «коммуникационный инструмент, направленный на активизацию усилий по созданию перспективных коммерческих технологий, новых продуктов (услуг), привлечение дополнительных ресурсов для проведения исследований и разработок на основе участия всех заинтересованных сторон (бизнеса, науки, государства и гражданского общества), а также на совершенствование нормативной правовой базы в области научнотехнологического и инновационного развития» ${ }^{3}$.

Отметим и приведенное выше определение в Государственной программе Российской Федерации «Информационное общество (2011-2020 годы)» 2010 г. «технологической платформы, обеспечивающей создание, функционирование и техническую поддержку федеральных, региональных и муниципальных сайтов в сети "Интернет" как “конструктора сайтов"».

Документы использовали различные наименования таких платформ. Помимо приведенного в предыдущем абзаце примера с технологической платформой, обеспечивающей создание, функционирование и техническую поддержку федеральных, региональных и муниципальных сайтов в сети «Интернет», можно привести еще и положения Стратегии развития информационного общества в Российской

${ }^{1}$ Утверждено распоряжением Правительства РФ от 6 сентября 2011 г. № 1540-p.
${ }^{2}$ Утверждена распоряжением Правительства РФ от 8 декабря 2011 г. № 2227-р.
${ }^{3}$ В указанном документе также были обозначены цели и функции создания технологических платформ: они рассматривались в качестве важного инструмента объединения (партнерства) усилий бизнеса, науки и государства по реализации приоритетных направлений модернизации и технологического развития российской экономики. Также использовалось понятие «механизм технологических платформ». В отношении него было указано, что он является одним из ключевых инструментов координации, в рамках которого наука, государство, бизнес-структуры и потребители выработают общее видение перспектив технологического развития соответствующей отрасли или технологического направления, а также сформируют и реализуют перспективную программу исследований и разработок. 
Федерации на 2017-2030 годы ${ }^{1}$, в которой говорится о: «различных технологических платформах» («для дистанционного обучения в целях повышения доступности качественных образовательных услуг»); «национальной технологической платформе онлайн-образования»; «национальной технологической платформе онлайн-медицины». В отдельных документах технологические платформы будут иметь наименования ${ }^{2}$. Однако каких-то специальных определений отдельных видов платформ в документах, в которых они выделяются, за редким исключением, нет.

Приведенные же выше определения технологической платформы носят очень общий характер, какие-то конкретные признаки таких платформ, их цели, задачи, функции и ценность (эффекты) из таких определений понять сложно. Обращает на себя внимание разброс подходов в документах относительно того, представляет ли она собой объект права или субъект. В одних документах о платформе говорится как об объекте: к примеру, в Стратегии инновационного развития Российской Федерации на период до 2020 года речь идет о технологической платформе как о коммуникационном инструменте; в Стратегии развития информационного общества в Российской Федерации на 2017-2030 годы отнесенность к объектам выражается косвенно, через определение понятия «экосистема цифровой экономики» («партнерство организаций, обеспечивающее постоянное взаимодействие принадлежащих им технологических платформ...»). В других документах «технологическая платформа» выступает в качестве субъекта. Так, в Стратегии развития морской портовой инфраструктуры в России до 2030 г., утвержденной в 2012 г., о ней говорится как об объединении компаний; в Федеральной научно-технической программе развития сельского хозяйства на 2017-2025 годы ${ }^{3}$ "технологические платформы» отнесены к «участникам комплексных научно-технических проектов» (наряду с другими субъектами).

О принципах, стадиях формирования, функциях и ценности (для различных субъектов) технологических платформ наиболее концентрированно написано в Стратегии социально-экономического развития Центрального федерального округа до 2020 года:

1 Утверждена Указом Президента Российской Федерации от 9 мая 2017 г. № 203.

${ }^{2}$ К примеру, Транспортная стратегии Российской Федерации на период до 2030 года (в редакции 2014 г.), утвержденная распоряжением Правительства РФ от 22 ноября 2008 г. № 1734-р (в редакции распоряжения Правительства РФ от 11 июня 2014 г. № 1032-р), указывает на технологическую платформу «Технологии экологического развития».

3 Утверждена постановлением Правительства РФ от 25 августа 2017 г. № 996. 
- основные принципы технологических платформ: объединение усилий наиболее значимых и заинтересованных сторон (государства, бизнеса, науки); обеспечение выработки и реализации долгосрочных (стратегических) приоритетов в масштабах определенных секторов экономики; технологическая модернизация в наиболее перспективных для развития экономики направлениях;

- стадии формирования и развития технологической платформы: определение облика сектора на долгосрочную перспективу, создание стратегической программы исследований и разработка плана по ее внедрению, в результате чего образуется постоянно уточняемый перечень проектов, подчиненный решению стратегических задач и учитывающий ресурсные ограничения;

- предназначение технологических платформ: решение нижеследующих системных проблем инновационной сферы:

a) ограниченный горизонт планирования научных исследований и разработок, низкая инновационная восприимчивость бизнеса;

б) фрагментарность сектора исследований и разработок, наличие проблем в трансформации результатов научно-исследовательских и опытно-конструкторских работ в коммерческие технологии;

в) возможное дублирование научно-исследовательских и опытноконструкторских работ, поддерживаемых государством, при слабом распространении полученных результатов;

г) наличие барьеров в распространении технологий, связанных с отраслевым регулированием;

д) отсутствие качественных инновационных проектов;

- результаты создания и развития технологических платформ (ценность, эффект):

а) для бизнеса: улучшение среды для инноваций и стимулирование спроса на инновационную продукцию; улучшение качества подготовки кадров с учетом необходимых технологических компетенций; финансовая поддержка реализации инновационных проектов; наличие новых возможностей для технологической модернизации и расширения горизонта планирования; выпуск принципиально новой продукции; расширение возможностей для выбора партнеров и селекция лучших контрагентов; политическая поддержка на мировых рынках и формирование международных альянсов по направлениям, характеризующимся высокими рисками и требующим объединения ресурсов; поддержка и внимание общественности и расширение спроса населения на инновационную продукцию (услуги);

б) для научной сферы: привлечение бизнеса к партнерству с научными организациями, демонстрационный эффект для бизнеса и 
расширение спроса бизнеса на научно-исследовательские и опытноконструкторские работы; включение в бизнес малых фирм, созданных научно-образовательными учреждениями; заполнение недостаточно разработанных сегментов в прикладной науке; формирование новых коопераций в научном секторе; формирование центров компетенций, в том числе на уровне подразделений научных и научно-образовательных организаций; формирование потенциала для реализации сложных проектов с множеством участников;

в) для государства: более четкое определении средне- и долгосрочных приоритетов научно-технологической политики; концентрация ресурсов на приоритетных направлениях модернизации экономики; обеспечение более четкой координации научно-исследовательских и опытно-конструкторских работ, финансируемых за счет бюджетных средств; выявление направлений совершенствования государственного регулирования, в том числе отраслевого; улучшение условий для распространения передовых технологий; повышение эффективности крупных компаний с государственным участием; повышение результативности бюджетных расходов.

Мы намеренно привели довольно обширную выдержку из документа, поскольку это, наверное, один из немногих документов, в которых соответствующие вопросы (цели, задачи, функции, ценность (эффекты) технологических платформ) описаны сколько-нибудь подробным образом.

И, тем не менее, отметим, что даже после прочтения этих положений никакой ясности с экономической сущностью и правовым режимом технологической платформы не образуется; по существу, в части целей и эффектов перед нами текст из серии «за все хорошее», но вот в чем оно конкретно выражается понять затруднительно ${ }^{1}$.

${ }^{1}$ Нет ясности с экономической сущностью и правовым режимом технологических платформ и в исследованиях, причем чаще экономических (юристы крайне редко пишут по этой тематике). Для примера можно привести два следующих определения:

- «технологическая платформа представляет собой концепцию инновационного развития приоритетных отраслей народного хозяйства на основе создания перспективных коммерческих технологий путем активизации усилий промышленного бизнеса, науки и государства» (см.: Злывко О.A. Разработка механизма реализации инвестиционных проектов на основе государственно-частного партнерства посредством технологических платформ: автореф. дис. ... канд. экон. наук. М., 2015. С. 8);

- технологическая платформа - это «комплексная негосударственная программа разработки и освоения крупномасштабных технологических инноваций на основе научно-технического и организационно-экономического сотрудничества и финансового участия заинтересованных государственных, бизнес-структур и научного сообщества» (см.: Желтоножко Т.А. Методы и инструменты управления разработкой и реализацией 
4. Еще одно понятие, которое встречается в стратегиях доцифровой эпохи - «научная платформа».

К примеру, в Стратегии развития медицинской науки в Российской Федерации на период до 2025 года ${ }^{1}$, утвержденной в 2012 г., под такой платформой понималась «интегрированная программа исследований по приоритетным направлениям и критическим технологиям развития медицинской науки, направленная на создание инновационных продуктов и технологий, реализуемая ведущими научными коллективами и исследователями».

Указанный документ предполагал формирование научных платформ по основным направлениям медицины; на основании таких платформ предполагалось осуществлять управление медицинскими исследованиями и реструктуризацию организаций медицинской науки; дорожные карты научных платформ, детализированные до проектов и продуктов, должны были стать основой для формирования государственных заданий государственным учреждениям, а также для программно-целевого финансирования науки. Впоследствии понятие «научная платформа» использовалось в целом ряде официальных документов ${ }^{2}$.

5. Можно отметить использование слова «платформа» и в других документах, к примеру:

- Стратегия развития малого и среднего предпринимательства в Российской Федерации на период до 2030 года ${ }^{3}$ упоминает «образовательную платформу», в рамках которой, как отмечается в документе, «на основе единой методологии будет консолидироваться информация об образовательных курсах и иных образовательных проектах,

инновационных направлений промышленной политики, основанных на применении технологических платформ: дис. ... д-ра экон. наук. М., 2016. С. 6).

Отметим, что понятие «технологическая платформа» не исчезло и в новой - цифровой - реальности, мало того, как показывает анализ специальных исследований, слово «технологическая» часто просто присоединяют к словам «цифровая» или «онлайн»и получается нечто вроде «технологической цифровой платформы», или «цифровых технологических платформ», или «технологических онлайн-платформ» (см., к примеру: Карцхия А.А. Гражданско-правовая модель регулирования цифровых технологий: дис. ... д-ра юрид. наук. М., 2019. С. 3, 4, 19 и др.). Такие конструкции возникают, потому что отсутствует единая терминология: как захотел исследователь, так и назвал.

1 Утверждена распоряжением Правительства РФ от 28 декабря 2012 г. № 2580-р.

${ }^{2}$ К примеру, см.: План мероприятий («дорожная карта») «Развитие лазерных, оптических и оптоэлектронных технологий (фотоники)», утв. распоряжением Правительства РФ от 24 июля 2013 г. № 1305-р; Критерии отбора медицинских организаций, участвующих в оказании медицинской помощи в рамках клинической апробации методов профилактики, диагностики, лечения и реабилитации, утв. постановлением Правительства РФ от 9 июля 2015 г. № 691.

3 Утверждена распоряжением Правительства РФ от 2 июня 2016 г. № 1083-р. 
предназначенных как для граждан, планирующих начать собственный бизнес, так и для действующих предпринимателей, а также организовано предоставление образовательных услуг с применением электронного обучения и дистанционных образовательных технологий, в том числе с использованием различных форматов (кейсы, деловые игры, курсы лекций и пр.)»;

- постановление Правительства РФ от 12 сентября 2014 г. № 929 «0 представлении Президенту Российской Федерации предложения о подписании Конвенции Совета Европы против манипулирования спортивными соревнованиями» в прилагаемой к этому документу Конвенции Совета Европы против манипулирования спортивными соревнованиями использует понятие «национальная платформа» для консолидации информации о случаях подозрительной деятельности, связанной с манипулированием спортивными соревнованиями, о незаконном, необычном или подозрительном размещении ставок на спортивные соревнования;

- Государственная программа Российской Федерации «Охрана окружающей среды» ${ }^{1}$ указывает на «научно-исследовательскую дрейфующую платформу “Северный полюс"» и «ледостойкую самодвижущуюся платформу “Северный полюс"»;

- Транспортная стратегия Российской Федерации на период до 2030 года (в редакции 2014 г.) указывает на «национальную платформу интеллектуальных транспортных систем» и «централизованную навигационно-информационную платформу»;

- Стратегия развития туризма в Российской Федерации на период до 2020 года $^{2}$ слово «платформа» использует в политико-правовом контексте, говоря о туризме как о «мощном инструменте просвещения и формирования нравственной платформы развития гражданского общества»;

- Концепция программы поддержки детского и юношеского чтения в Российской Федерации ${ }^{3}$ указывает на «новые мобильные, интерактивные и игровые платформы» для целей популяризации чтения;

- Стратегия развития экспорта гражданской продукции авиационной промышленности Российской Федерации на период до 2025 года ${ }^{4}$, утвержденная в 2017 г., использует понятия «офшорная платформа», «лизинговая платформа», «кредитно-лизинговая платфор-

\footnotetext{
1 Утверждена постановлением Правительства РФ от 15 апреля 2014 г. № 326.

2 Утверждена распоряжением Правительства РФ от 31 мая 2014 г. № 941-р.

3 Утверждена распоряжением Правительства РФ от 3 июня 2017 г. № 1155-р.

4 Утверждена распоряжением Правительства РФ от 18 сентября 2017 г. № 1997-р.
} 
ма». Под «лизинговой платформой» в этом документе понимается «центр компетенций по авиационному лизингу»;

- Стратегия развития информационного общества в Российской Федерации на 2017-2030 годы упоминает «информационные платформы» (для распределения достоверной и качественной информации российского производства).

Указанный перечень примеров можно продолжать.

6. Как хорошо заметно, никакой системы в использовании слова «платформа» в доцифровую эпоху развития отечественного права ${ }^{1}$ нет.

Это слово традиционно использовалось (и продолжает, естественно, использоваться) для образования специальной терминологии в таких областях, как правовое регулирование организации железнодорожного транспорта, а также для формирования терминов, обозначающих специфическое имущество для добычи полезных ресурсов в море. Весьма естественно выглядит использование этого слова для образования понятий, необходимых для описания стратегических целей и задач в области автомобилестроения.

А вот использование слова «платформа» для описания отдельных аспектов дистанционного электронного взаимодействия или процессов консолидации каких-то ресурсов, знаний, навыков, информации и компетенций («технологическая платформа», «научная платформа» и проч.) выглядит не в полной мере продуманно. Отчасти это результат заимствования специальной терминологии из практики зарубежного регулирования, отчасти - перенос в право технической терминологии.

В результате мы получили лавинообразный рост использования этого слова в программных, концептуальных и стратегических документах. При этом приходится констатировать, что его использование приняло бессистемный характер; оправданность его использования в каком-либо контексте зависит исключительно от образования и опыта разработчика соответствующего документа. В отдельных исследованиях можно встретить суждения, объясняющие (и отчасти оправдывающие) сложившееся положение особенностями периода развития. К примеру, П. У. Кузнецов отмечает, что «на государственном уровне создавались первые концептуальные условия информационной политики... Это был период массового внедрения компьютерной техники и информационных технологий в реальный сектор экономики, практику государственного управления и общественную жизнь. Поэтому тексты, в которых формулировались основные положения государст-

1 То есть до использования этого слова для описания новых экономических явлений, объединяемых понятием «цифровая экономика». 
венной политики, больше напоминали развернутые концептуальные планы общественного развития в информационной сфере» ${ }^{1}$.

С этим мнением можно было бы согласиться, если бы период бурного и бессистемного использования слова «платформа» продолжился определенной рефлексией, закончившейся выработкой концептуальных подходов и проектов конкретных правовых решений. Однако этого не произошло. Дефектный подход, заключающийся в хаотичном использовании слова «платформа» в официальных текстах, отсутствии даже попыток дать какое-то общее определение платформы, наличии многочисленных определений (часто имплицитного характера), описывающих совершенно разные феномены, продолжает применяться, причем уже и в новую - цифровую - эпоху развития отечественного права и новой - цифровой - жизни платформ.

«Платформа» как одно из ключевых понятий

для описания новой цифровой реальности в российском праве

7. Развитие цифровой экономики, а скорее, даже формулирование государством целей и задач по развитию цифровой экономики ${ }^{2}$, послужило толчком для нового широкого использования слова «платформа» в нормативных документах. Количество этих документов (различных видов) к настоящему времени очень значительно; мы рассмотрим их по времени появления (соответственно: документы 2017, 2018, 2019 и 2020 гг.). Такой подход позволит последовательно проанализировать содержание документов, вычленить соответствующие положения о платформах, найти определения (в том числе имплицитные) платформ различных видов, сделать выводы о развитии нормативного регулирования. В свою очередь, это позволит (в следующем разделе) «наложить» соответствующие выводы на выводы из исследований экономического и правового характера в части определения сущности цифровых платформы и их классификаций.

8. Первые упоминания о платформах в новом значении этого слова (как платформа онлайн) в нормативных актах относятся к 2017 г.

Прежде всего следует назвать Программу «Цифровая экономика Российской Федерации» 2017 года ${ }^{3}$ (далее - Программа или Программа 2017 г.), в которой понятие «платформа» использовано 64 раза.

${ }^{1}$ См.: Кузнецов П.У. Феномены и правовые фикции цифровой сферы // Российское право: образование, практика, наука. 2019. № 6. С. 72.

2 См.: Габов А. В. Изменения в праве как следствие развития цифровой экономики // Пермский юридический альманах. 2020. № 3. С. 39-48.

3 Утверждена распоряжением Правительства Российской Федерации от 28 июля 2017 г. № 1632-p. 
Среди особенностей этого документа (в интересующем нас контексте) отметим следующие:

а) использование понятия «цифровая платформа» как отдельно, так и с добавлением некоторых качественных характеристик (к примеру, «прорывные и перспективные сквозные цифровые платформы»);

б) о цифровых платформах в Программе говорится не как о каком-то феномене из будущего времени (который еще только предстоит создать), а как о явлении известном, существующем. В качестве примеров таких платформ приводится отечественный опыт в части создания и функционирования «цифровой платформы предоставления государственных и муниципальных услуг», «платформы для проведения платежей, создаваемых кредитными организациями» ${ }^{\text {; }}$

в) платформы были названы одним из трех уровней цифровой экономики², т. е. была сделана попытка определить место цифровых платформ в новом цифровом мире;

г) Программа содержала упоминание о многочисленных видах платформ.

Когда мы используем слово «вид», то подразумеваем конкретные названия платформ, которые есть в документе, а также группы платформ, которые образуются в Программе путем добавления к словам

1 Вот соответствующий фрагмент: «В России успешно развиваются цифровые платформы, однако их виды и подходы к созданию существенным образом различаются. Так, Россия достигла значительных успехов в развитии цифровой платформы предоставления государственных и муниципальных услуг, в том числе за счет установления требований об интероперабельности систем, использования информации из других систем, в том числе платежных. Успешно развиваются федеральная государственная информационная система "Единая система идентификации и аутентификации в инфраструктуре, обеспечивающей информационно-технологическое взаимодействие информационных систем, используемых для предоставления государственных и муниципальных услуг в электронной форме” и платформы для проведения платежей, создаваемые кредитными организациями».

2 «Цифровая экономика представлена 3 следующими уровнями, которые в своем тесном взаимодействии влияют на жизнь граждан и общества в целом:

- рынки и отрасли экономики (сферы деятельности), где осуществляется взаимодействие конкретных субъектов (поставщиков и потребителей товаров, работ и услуг);

- платформы и технологии, где формируются компетенции для развития рынков и отраслей экономики (сфер деятельности);

- среда, которая создает условия для развития платформ и технологий и эффективного взаимодействия субъектов рынков и отраслей экономики (сфер деятельности) и охватывает нормативное регулирование, информационную инфраструктуру, кадры и информационную безопасность». 
«платформа» или «цифровая платформа» дополнительных качественных характеристик 1 .

Конкретные виды цифровых платформ содержит раздел Программы «дорожная карта», в которой указываются такие виды платформ:

- «коммуникационная платформа для взаимодействия участников цифровых платформ и центров компетенций при проведении исследований и разработок по направлениям “сквозных" технологий»;

- «пилотная цифровая платформа для исследований и разработок по одному из направлений “сквозных" технологий»;

- «индустриальные платформы»;

- “"сквозные” цифровые платформы, предоставляющие субъектам цифровой экономики максимально широкий набор инструментов и интерфейсов, обеспечивающих обработку различного вида данных и предоставление цифровых услуг»;

- «сетевая платформа для управления результатами интеллектуальной деятельности»;

- «цифровые платформы, нацеленные на реализацию “сквозных" технологий»;

- «цифровая платформа сбора, обработки и распространения пространственных данных для нужд картографии и геодезии, обеспечивающая потребности граждан, бизнеса и власти»;

- «отечественная цифровая платформа сбора, обработки, хранения и распространения данных, дистанционного зондирования Земли, обеспечивающая потребности граждан, бизнеса и власти»;

- «отечественные платформы, обеспечивающие единую доверенную среду для работы с данными»;

- «государственная единая облачная платформа»;

д) Программа не содержит определения того, что понимается под «платформой» или под конкретными видами платформ.

А вот в другом документе 2017 г. - Основных направлениях реализации цифровой повестки Евразийского экономического союза до 2025 года $^{2}$ (в нем слово платформа использовано 13 раз) - понятие «цифровая платформа» раскрыто следующим образом: «система средств, поддерживающая использование цифровых процессов, ресурсов и сервисов значительным количеством субъектов цифровой экосистемы и обеспечивающая возможность их бесшовного взаимодействия».

${ }^{1}$ К примеру, Программа указывает на успешное функционирование к 2024 г. «не менее 10 отраслевых (индустриальных) цифровых платформ для основных предметных областей экономики».

2 Утверждены решением Высшего Евразийского экономического совета от 11 октября 2017 г. № 12. 
Назвать данное определение в полной мере ясным нельзя. Нельзя, конечно, отказать его авторам в некотором изяществе, которое позволило несколькими словами описать цифровую платформу, однако заметим следующее:

- во-первых, терминология, использованная в этом определении, исключительно неопределенная («средства», «процессы», «субъекты»). Таким образом, авторы пытались охватить необъятное - дать такое определение, которое позволит «собрать» в него весь мир платформ;

- во-вторых, определение носит оттенок технический: в нем используется технический сленг, например «бесшовное взаимодействие». По существу, понять из такого определения хоть что-нибудь, кроме (предположительно) замысла авторов, нереально, а уж тем более построить вокруг такого определения какое-либо внятное регулирование ${ }^{1}$.

В Основных направлениях реализации цифровой повестки Евразийского экономического союза до 2025 года есть упоминания и об отдельных видах платформ, например:

- «глобальные цифровые платформы»;

- «цифровые кросс-отраслевые платформы»;

- «цифровая платформа Союза».

1 Любопытно отметить, что подобное определение не нашло реализации в принятых позднее нормативных актах государств - членов ЕАЭС. В них либо вообще не дается общего определения цифровой платформы (к примеру, см.: Государственная программа развития цифровой экономики и информационного общества на 2016-2020 годы, утв. постановлением Совета Министров Республики Беларусь 23 марта 2016 г. № 235. URL: https://www.pravo.by/upload/docs/op/C21600235_1459458000.pdf (дата обращения: 22.12.2020); Декрет Президента Республики Беларусь от 21 декабря 2017 г. № 8 «0 развитии цифровой экономики». URL: https://pravo.by/document/?guid=12551\&p0=Pd17 00008\&p1=1\&p5=0 (дата обращения: 22.12.2020), либо дается иное ее определение.

К примеру, Государственная Программа «Цифровой Казахстан», утв. постановлением Правительства Республики Казахстан от 12 декабря 2017 года № 827, - документ, принятый практически сразу после Основных направлений реализации цифровой повестки Евразийского экономического союза до 2025 года, определяет цифровую платформу много проще - «площадка, обеспечивающая комплекс цифровых процессов взаимодействия двух или более различных субъектов цифрового взаимодействия». URL: http://adilet.zan.kz/rus/docs/P1700000827 (дата обращения: 22.12.2020); https://digitalkz.kz/wp-content/uploads/2020/03/\%D0\%A6\%D0\%9A-\%D1\%80\%D1\%83\% D1\%81.pdf (дата обращения: 22.12.2020).

В нормативных документах Республики Беларусь (см.: URL: https://www.pravo.by/ upload/docs/op/P31900461_1576616400.pdf (дата обращения: 22.12.2020) встречаем термин «республиканская платформа», под которым понимается «совокупность программно-технических средств и информационных систем, подключенных к ЕРСПД, позволяющая оператору оказывать услуги РЦОД ("республиканский центр обработки данных" - прим. А. Г.) и услуги республиканской платформы, в том числе с использованием технологий облачных вычислений». 
Любопытно, что упоминания о таких видах платформ не встречались в тот период в документах государств - членов ЕАЭС и практически не встречаются сегодня 1 .

Интересны оценки платформ, данные в этом документе. Здесь указывается, что цифровые платформы (или «комплексы цифровых платформ»²) - это основа цифровой трансформации отраслей экономики; они названы основным источником капитализации в цифровой экономике; они же признаются основным элементом развития технологической деятельности в рамках всесторонней кооперации хозяйствующих субъектов государств - членов Евразийского экономического союза. Цифровые платформы называются «цифровым активом» резидентов государств - членов Евразийского экономического союза.

В 2017 г. Банком России была презентована концепция проекта «Маркетплейс» ${ }^{3}$. То, что названо «проектом» на сайте Банка России, также именуется системой, объединяющей финансовые платформы, поставщиков финансовых продуктов и услуг, регистраторов финансовых транзакций и сайтов-агрегаторов 4 . При этом в отдель-

${ }^{1}$ К примеру, в Государственной Программе «Цифровой Казахстан» всего 19 упоминаний о платформах; при этом встречаются такие виды: «банковские и небанковские платформы»; «технологические платформы для обеспечения межинституциональной удаленной идентификации населения»; «открытые платформы в финансовом секторе»; «платформа для электронной торговли между фермерами, оптовораспределительными центрами, торговыми сетями, рынками и стабилизационными продовольственными фондами»; «единая платформа, агрегирующая аналитическую и статистическую информацию о рынке труда»; «цифровая платформа для заключения трудовых отношений»; «единая платформа для малого и среднего бизнеса»; «платформа по выставлению электронных счетов-фактур»; «интеграционная платформа здравоохранения»; «единая аналитическая платформа, позволяющая отражать информацию для представления на уровне центральных государственных органов, а также местных исполнительных органов»; «геоинформационная платформа специального назначения»; «единая платформа для принятия управленческих решений»; «национальная платформа открытого образования».

В нормативных документах Республики Беларусь встречается понятие «криптоплатформа» или «республиканская платформа».

2 Что это за феномен, в документе не поясняется.

${ }^{3}$ Cм.: URL: http://www.cbr.ru/press/event/?id=1707\#highlight=\%D0\%BC\%D0\%B0\% D1\%80\%D0\%BA\%D0 \%B5\%D1\% 82\%D0\%BF\%D0\%BB\%D0\%B5\%D0\%B9\%D1\%81 (дата обращения: 12.12.2020).

${ }^{4}$ Cм.: URL: http://www.cbr.ru/fintech/market_place/\#highlight=\%D0\%BC\%D0\%B0\% D1\%80\%D0\%BA\%D0\% B5\%D1\%82\%D0\%BF\%D0\%BB\%D0\%B5\%D0\%B9\%D1\%81 (дата обращения: 12.12.2020). 
ных документах Банка России используется понятие «платформа “Маркетплейс"»1.

Любопытно, что в 2017 г. законодательство Российской Федерации о контрактной системе в сфере закупок товаров, работ, услуг для обеспечения государственных и муниципальных нужд пополнилось положениями об электронных торговых площадках 2 .

Само это понятие новым не являлось. Его использовали в соответствующих законодательных массивах и ранее, более того, оно использовалось (и используется) в документах евразийской интеграции ${ }^{3}$. Однако введение соответствующих положений в нормативные акты в 2017 г. - а именно в этом году и появилось понятие «цифровая платформа» в нормативном поле - выглядело несколько странно, поскольку функционал электронной площадки и цифровой платформы до известной степени совпадают.

9. В 2018 г. «вторжение» цифровых платформ в правовой лексикон продолжилось.

Был сформулирован важный политико-правовой посыл в части функционала цифровых платформ: в Послании Президента РФ Федеральному Собранию от 1 марта 2018 г. было указано, что «активное внедрение цифровых технологий и платформ позволит последовательно идти к повышению прозрачности и обелению экономики». Отметим, что именно в части платформ, а не в целом применительно к новым явлениям цифровой экономики это редкий пример формулирования целей их существования. Данный текст показывает, что под цифровыми платформами здесь понимались прежде всего те, которые предоставляют сервисы по обороту товаров, работ и услуг, а не те многочисленные платформы, названные в Программе 2017 г., цель которых (судя из названия) в основном сводилась к формированию новой системы взаимодействия субъектов для получения какой-либо информации.

${ }^{1}$ См.: Аналитический доклад «Конкуренция на финансовом рынке». Подготовлен Банком России при участии ФАС России кXXVII Международному финансовому конгрессу (6-8 июня 2018 года, г. Санкт-Петербург) (см.: URL: http://www.cbr.ru/statichtml/ file/41186/20180607_report.pdf (дата обращения: 12.12.2020).

${ }^{2}$ См.: Федеральный закон от 31 декабря 2017 г. № 504-Ф3 «0 внесении изменений в Федеральный закон “О контрактной системе в сфере закупок товаров, работ, услуг для обеспечения государственных и муниципальных нужд”».

${ }^{3}$ См.: Соглашение о государственных (муниципальных) закупках, заключенное в г. Москве 9 декабря 2010 г. правительствами Республики Беларусь, Республики Казахстан и Российской Федерации; Протокол о порядке регулирования закупок (приложение № 25 к Договору о Евразийском экономическом союзе (Астана, 29 мая 2014 года)). 
В 2018 г. появились три документа, в которых было указано на необходимость создания цифровых платформ, а именно:

а) Указ Президента РФ от 7 мая 2018 г. № 204 «0 национальных целях и стратегических задачах развития Российской Федерации на период до 2024 года» (п. 13). В этом документе Правительству РФ давалось, среди прочего, поручение создать «цифровую платформу, ориентированную на поддержку производственной и сбытовой деятельности субъектов малого и среднего предпринимательства, включая индивидуальных предпринимателей»;

б) Основные направления деятельности Правительства Российской Федерации на период до 2024 года ${ }^{1}$. Этот документ использует слово «платформа» 7 раз. В нем, помимо общего понятия «цифровая платформа», упоминаются также и конкретные платформы, а именно:

- «единая платформа по принципу “одного окна" с целью обеспечения граждан единой точкой доступа для взаимодействия с государством»;

- «единая цифровая платформа научного и научно-технического взаимодействия, организации и проведения совместных исследований в удаленном доступе»;

- «платформы цифровых сервисов для перевода деятельности, документооборота и механизмов взаимодействия органов государственной власти и органов местного самоуправления в цифровой формат»;

- «творческая платформа "Россия - страна возможностей"».

В тексте данного документа неоднократно встречается понятие, образованное с использованием слова «платформа», - «платформенное решение». Это понятие впоследствии будет использоваться неоднократно в различных документах. Как и в случае с «платформами», никакого общего определения «платформенного решения» в документе не было. Из текста можно лишь уяснить (это, конечно, толкование), что внедрение платформенных решений - это и есть «цифровизация» 2 . Нет определения того, что такое «платформенное решение», и в других документах вплоть до сегодняшнего дня. Подобие определения (в виде объяснения в скобках) можно встретить в Стратегии развития электронной промышленности Российской

1 Утверждены Председателем Правительства РФ 29 сентября 2018 г.

2 Приведем следующий фрагмент: «Будут осуществляться меры по внедрению цифровых технологий и платформенных решений ("цифровизации") в практическую деятельность органов государственного управления федерального, отраслевого и регионального уровней». 
Федерации на период до 2030 года ${ }^{1}:$ «базы данных, языки программирования и проектирования, системы автоматизированного проектирования и т. д.». Однако очевидно, что перед нами техническое объяснение понятия «платформенное решение», которое не может быть использовано в программных документах и документах стратегического планирования;

в) Паспорт национальной программы «Цифровая экономика Российской Федерации» 2018 г. ${ }^{2}$ (далее - Паспорт 2018 г.), который фактически не применялся. В этом документе многочисленные «платформы» упоминались 30 раз, а именно:

- «государственная единая облачная платформа»;

- «инвестиционные платбормы»;

- «информационная система электронного правительства как цифровая платформа, обеспечивающая предоставление государственных услуг, исполнение функций, обмен данными и идентификацию по новой модели»;

- «общественная сетевая платформа управления правами на результаты интеллектуальной деятельности и средства индивидуализации, обеспечивающая развитие сервисов управления такими правами в цифровой среде»;

- «платформа сбора данных промышленного интернета вещей (приборов автоматического измерения показателей), используемая для реализации динамической оценки рисков в видах государственного и муниципального контроля (надзора), обеспечено подключение органов контроля (надзора) для использования получаемых сведений в составе, предусмотренном утвержденными ведомственными моделями данных»;

- «открытая общественная сетевая платформа» как основа инфраструктуры поиска патентной информации и средств индивидуализации;

- «отечественная цифровая платформа сбора, обработки, хранения и распространения данных дистанционного зондирования Земли из космоса, обеспечивающая потребности граждан, бизнеса и власти»;

- «универсальная цифровая платформа инвентаризации, учета и контроля состояния всех видов энергоресурсов имущественных комплексов государственной и муниципальной форм собственности»;

- «универсальные цифровые платформы управления городскими ресурсами»;

1 Утверждена распоряжением Правительства РФ от 17 января 2020 г. № 20-р.

2 Утвержден президиумом Совета при Президенте РФ по стратегическому развитию и национальным проектам, протокол от 24 декабря 2018 г. № 16. 
- «не менее двух пилотных цифровых платформ для исследований, и разработок, и использования результатов интеллектуальной деятельности»;

- «платформа идентификации, включая биометрическую идентификацию, облачную квалифицированную электронную подпись, цифровые профили гражданина и юридического лица, а также единое пространство доверия электронной подписи цифровой платформы электронного правительства» (на базе Единой системы идентификации и аутентификации);

- «платформы исполнения государственных функций, в том числе при осуществлении контрольной (надзорной) деятельности»;

- «единая цифровая платформа обеспечения деятельности Президента Российской Федерации, Председателя Правительства Российской Федерации, палат Федерального Собрания, Совета Безопасности Российской Федерации, Администрации Президента Российской Федерации, Аппарата Правительства Российской Федерации при осуществлении ими свочх полномочий»;

- «платформы поиска работы и подбора персонала на базе информационно-аналитической системы Общероссийская база вакансий "Работа в России"»;

- «цифровая платформа для взаимодействия в сфере стратегического управления в целях согласованности действий участников стратегического планирования на всех уровнях государственного управления в достижении стратегических приоритетов».

В 2018 г. Банком России были приняты Основные направления развития финансовых технологий на период 2018-2020 годов ${ }^{1}$. Этот документ предусматривал развитие целого ряда платформ:

- «платформы для удаленной идентификации»;

- «платформы быстрых платежей» ${ }^{3}$;

- «платформы-маркетплейса для финансовых услуг и продуктов»4;

${ }^{1}$ Cм.: URL: http://www.cbr.ru/Content/Document/File/85540/ON_FinTex_2017.pdf (дата обращения: 12.12.2020).

${ }^{2}$ Как отмечается в документе, создание и развитие платформы для удаленной идентификации позволит перевести финансовые услуги в цифровую среду, повысить доступность финансовых услуг для потребителей, в том числе людей с ограниченными возможностями, пожилого и маломобильного населения, а также увеличить конкуренцию на финансовом рынке.

${ }^{3}$ Как отмечается в документе, платформа быстрых платежей обеспечит возможность проведения онлайн-переводов на финансовом рынке в режиме реального времени (365/24/7) с использованием смартфонов, мессенджеров, QR-кода и т. д.

${ }^{4}$ Как отмечается в документе, платформа-маркетплейс для финансовых услуг и продуктов позволит повысить удобство, прозрачность и оперативность получения услуг клиентами в режиме «единого окна», а также устранить барьеры для доступа 
- «платформы для регистрации финансовых сделок» ${ }^{l}$;

- «платформы для облачных сервисов»;

- «платформы на основе технологии распределенных реестров»3.

Как хорошо видно из документов, принятых в 2018 г., рефлексии в части уяснения содержания понятия «цифровая платформа» не произошло; наоборот, расширялось применение и этого понятия, и производных от него («платформенное решение»).

При этом 2018 г. интересен тем обстоятельством, что в праве (Закон РФ от 7 февраля 1992 г. № 2300-1 «0 защите прав потребителей») появилось ${ }^{4}$ еще одно новое понятие - «агрегатор информации о товарах (услугах)»5.

В указанном законе это понятие прямо не раскрывается, хотя его содержание можно уяснить из определения понятия «владелец агрегатора информации о товарах (услугах)»: агрегатор информации о товарах (услугах) - это программа для электронных вычислительных

к финансовым услугам и продуктам для клиентов; платформа-маркетплейс позволит обеспечить возможность поиска и удобного предоставления востребованных финансовых услуг и продуктов для клиентов всеми участниками рынка наряду с другими финансовыми площадками, в том числе с применением чатов, ботов и робо-эдвайзинга; платформа будет предусматривать консолидацию данных по предложениям участников финансовой экосистемы, анализ потребностей и персонализацию предложений для клиентов. Планируется разработка дизайна и проведение пилотирования платформымаркетплейса, разработка дорожной карты по правовому и технологическому обеспечению реализации проекта и запуск платформы на финансовом рынке.

1 Как отмечается в документе, платформа для регистрации финансовых сделок обеспечит регистрацию сделок на финансовом рынке в едином реестре, к которому будет предоставлен доступ для всех участников, и получение информации по сделкам в режиме «единого окна».

2 Как отмечается в документе, платформа для облачных сервисов будет являться инфраструктурным решением, предоставляющим доступ участникам финансового рынка к облачным ресурсам внешних провайдеров (например, сети, системы хранения, приложения и сервисы) и позволяющим участникам финансового рынка на их основе размещать собственные прикладные сервисы с обеспечением необходимых требований и условий в отношении информационной безопасности.

${ }^{3}$ Как отмечено в документе, платформа на основе технологии распределенных реестров является распределенной системой хранения и обмена финансовой информацией и доверенной средой для ее участников для реализации финансовых сервисов с применением российской криптографии.

${ }^{4}$ После принятия Федерального закона от 29 июля 2018 г. № 250-Ф3 «0 внесении изменений в Закон Российской Федерации «О защите прав потребителей». Отметим, что до этого в 2018 г. появилось понятие «единый агрегатор торговли» (см.: распоряжение Правительства РФ от 28 апреля 2018 г. № 824-р «0 создании единого агрегатора торговли»).

${ }^{5}$ Отметим, что нашему праву понятие «агрегатор» было уже известно. К примеру, в 2016 г. появилось понятие «новостной агрегатор» (Федеральный закон от 23 июня 2016 г. № 208-Ф3 «0 внесении изменений в Федеральный закон “Об информации, информационных технологиях и о защите информации” и Кодекс Российской Федерации об административных правонарушениях»). 
машин и (или) сайт и (или) страница сайта в информационнотелекоммуникационной сети Интернет, владельцы которых предоставляют потребителю в отношении определенного товара (услуги) следующие возможности:

- одновременно ознакомиться с предложением продавца (исполнителя) о заключении договора купли-продажи товара (договора возмездного оказания услуг);

- заключить с продавцом (исполнителем) договор куплипродажи (договор возмездного оказания услуг);

- произвести предварительную оплату указанного товара (услуги) путем перевода денежных средств владельцу агрегатора в рамках применяемых форм безналичных расчетов ${ }^{1}$.

Что такое «агрегатор информации о товарах (услугах)»?

В пояснительной записке к проекту Федерального закона № 126869-7 «0 внесении изменений в Закон Российской Федерации “О защите прав потребителей” (который стал впоследствии Федеральным законом от 29 июля 2018 г. № $250-Ф 3$ «0 внесении изменений в Закон Российской Федерации “О защите прав потребителей”») агрегатор квалифицирован как «информационный посредник, вступающий с потребителями в возмездные отношения, но сам при этом не заключающий сделки по купле-продаже товаров (возмездному оказанию услуг)».

Однако такое определение не в полной мере соответствует тому, что написано в Законе РФ от 7 февраля 1992 г. № 2300-1 «0 защите прав потребителей», поскольку в нем, как мы отметили, имеется определение «владельца агрегатора информации о товарах (услугах)»; из него ясно следует, что агрегатор - это объект прав (исключительных) какого-то лица («владельца»).

Но основная проблема здесь не в плоскости координат «субъект объект», а в определении сущности.

Пояснительная записка к проекту Федерального закона № 126869-7 говорит о такой сущности, как информационное посредничество, тогда как уже закон предполагает, что через агрегатор не просто распространяется информация, но совершаются и исполняются сделки, т. е. перед нами посредник более широкого профиля.

По существу-то, эта деятельность (которую закон закрепляет за агрегатором) - типичный «функционал» цифровой платформы. Любопытно, что в указанной пояснительной записке к проекту Феде-

${ }^{1}$ В соответствии с п. 3 ст. 16.1 Закона РФ от 7 февраля 1992 г. № 2300-1 «0 защите прав потребителей» и Федеральным законом от 27 июня 2011 г. № 161-Ф3 «0 национальной платежной системе». 
рального закона № 126869-7 было отмечено, что соответствующий законопроект был разработан под воздействием опыта функционирования и регулирования онлайн-платформ в Европейском Союзе ${ }^{1}$. Говоря иначе, если откинуть долгие объяснения и рассуждения, агрегатор информации о товарах (услугах) - это цифровая платформа 2 .

Отметим, что во многих исследованиях между понятием «цифровая платформа» и «агрегатор» ставится знак равенства ${ }^{3}$, хотя вопрос этот требует не просто какого-то дополнительного решения, но четкого размежевания, поскольку, помимо указанного агрегатора информации о товарах (услугах), в нашем праве имеются и другие агрегаторы. К примеру, в 2019 г. ${ }^{4}$ в законодательстве о платежной системе появились положения о «платежном агрегаторе» (ст. 3, 9.1, 14.1 Федерального закона от 27 июня 2011 г. № 161-Ф3 «О национальной платежной системе»).

Интересно отметить, что определение агрегатора, приведенное нами выше (как результат анализа определения владельца агрегатора в Законе РФ от 7 февраля 1992 г. № 2300-1 «0 защите прав потребителей»), показывает, что под ним понимается сайт в сети Интернет (страница сайта) и/или программа для ЭВМ. Таким образом, для

1 Приведем соответствующий фрагмент пояснительной записки: «Не урегулирована деятельность так называемых “товарных агрегаторов”, которые, не являясь реальными продавцами товаров или исполнителями услуг, выступают в качестве непосредственных получателей денежных средств от потребителей в счет оплаты тех товаров (услуг), которые в значительных масштабах (объемах) аккумулируются ими на своих интернет-ресурсах (сайтах). Директивой Европейского парламента и Совета Европейского Союза от 25 октября 2011 г. 2011/83/ЕС данная тенденция учтена и определено понятие "дистанционные контракты" (организованные схемы дистанционных продаж товаров или дистанционного оказания услуг, которые должны включать схемы, предлагаемые третьими лицами через онлайн-платформы, используемые продавцами (исполнителями), но не являющимися ими). При этом Директива обязывает такого информационного посредника предоставлять до заключения договора не только всю необходимую информацию о товаре (услуге), но и о продавце (исполнителе), в интересах которого он действует (информацию о наименовании, фактическом адресе, телефонном номере, номере факса, адресе электронной почты и др.)».

2 Об этом также см.: Габов А. В. Правовое регулирование краудфандинга в России: учеб. пособие. Белгород: ИД «БелГУ» НИУ «БелГУ», 2020. С. 19-20.

${ }^{3}$ См.: Карихия А. А. Гражданско-правовая модель регулирования цифровых технологий... С. 3, 19, 20, 21, 87; Аюшеева И. 3. Гражданско-правовые сообщества в условиях экономики совместного потребления // Актуальные проблемы российского права. 2020. Т. 15, № 6. С. 97; Алексеенко А. П. Регулирование деятельности электронных платформ по Закону КНР «Об электронной коммерции» // Юрист. 2020. № 7. С. 62-68 и ряд др. работ.

${ }^{4}$ См.: Федеральный закон от 3 июля 2019 г. № 173-Ф3 «0 внесении изменений в Федеральный закон “О национальной платежной системе” и отдельные законодательные акты Российской Федерации». 
целей правового регулирования индифферентны иные качественные характеристики, которые в экономических отношениях связывают с платформой (определенное оборудование, к примеру): важно, чтобы соответствующий сайт (программа) обладал определенным «функционалом» - предоставляла субъектам указанные в определении возможности получения информаџии, совершения и исполнения сделок. Совершенно очевидно, что перед нами исключительно функциональный подход, реализованный для целей государственного регулирования. И, как показывает практика Федеральной антимонопольной службы, эту задачу соответствующее определение решает вполне успешно ${ }^{1}$.

Тем не менее такой подход порождает известную проблему, которая со всей остротой обозначится чуть позднее - в связи с принятием Федерального закона от 2 августа 2019 г. № 259-Ф3 «0 привлечении инвестиций с использованием инвестиционных платформ и о внесении изменений в отдельные законодательные акты Российской Федерации»: как отличить регулируемую деятельность (через «платформу») от нерегулируемой (через «обычный» сайт, но не платфор-

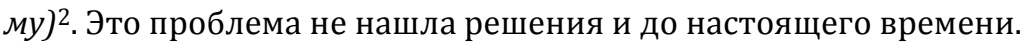

10. Дальнейшее развитие тема платформ получила в действующем Паспорте Национального проекта «Национальная программа “Цифровая экономика российской Федерации”»", утвержденном в 2019 г. (далее - Паспорт 2019 г.).

В Паспорте 2019 г. имеются десятки упоминаний о различных конкретных платформах (часть из которых упоминалась в предыдущих из указанных выше документов), в том числе функционирующих в составе иных платформ (т. е. предлагается даже некоторая иерархия, впрочем, никак не описанная):

- «государственная единая облачная платформа»;

1 Что показывает анализ решении ФАС России по делу № 11/01/10-41/2019 (дело «Booking.com») (см.: URL: https://br.fas.gov.ru/ca/upravlenie-po-kontrolyu-za-gosudarstvennymi-i-munitsipalnymi-informatsionnymi-sistemami/cdf15018-ef29-40e8-acbd-d39edc8 aee39/?query=booking.com (дата обращения - 09.02.2021).

Анализ этого решения также см.: Комиссаров Г. Booking.com: что ждет агрегатор в связи с решением ФАС России? // URL:https://zakon.ru/blog/2021/01/06/bookingcom_ chto_zhdet_agregator_v_svyazi_s_resheniem_fas_rossii (дата обращения - 09.02.2021).

${ }^{2}$ Об этом также см.: Габов А. В. Правовое регулирование краудфандинга в России... C. 18-19.

3 Утвержден протоколом заседания президиума Совета при Президенте Российской Федерации по стратегическому развитию и национальным проектам от 4 июня 2019 г. № 7. 
- «общественная сетевая платформа управления правами на результаты интеллектуальной деятельности и средства индивидуализации, обеспечивающая развитие сервисов управления такими правами в цифровой среде»;

- «отечественная цифровая платформа сбора, обработки, хранения и распространения данных дистанционного зондирования Земли из космоса, обеспечивающая потребности граждан, бизнеса и власти»;

- «универсальная цифровая платформа инвентаризации, учета и контроля состояния всех видов энергоресурсов имущественных комплексов государственной и муниципальной форм собственности»;

- «цифровая унифицированная платформа жилищно-коммунального комплекса для инвентаризации, учета и контроля оказания коммунальных услуг, состояния всех видов энергоресурсов, включая технологии сбора данных посредством интернета вещей, состояния имущественных комплексов»;

- «пилотная цифровая платформа для исследований и разработок и использования результатов интеллектуальной деятельности» (о ней говорится во множественном числе);

- «платформа идентификации, включая биометрическую идентификацию, облачную квалифицированную электронную подпись, цифровые профили гражданина и юридического лица, а также единое пространство доверия электронной подписи» (на базе Единой системы идентификации и аутентификации);

- «платформа межведомственного взаимодействия и обмена данными, в том числе нормативной справочной информацией» (на базе системы межведомственного электронного взаимодействия и единой системы нормативной справочной информации);

- «единая цифровая платформа обеспечения деятельности Президента Российской Федерации, Председателя Правительства Российской Федерации, палат Федерального Собрания, Совета Безопасности Российской Федерации, Администрации Президента Российской Федерации, Аппарата Правительства Российской Федерации при осуществлении ими свочх полномочий»;

- «платформа поиска работы и подбора персонала на базе информационно-аналитической системы Общероссийская база вакансий "Работа в России"»;

- «платформа для взаимодействия в сфере стратегического управления в целях согласованности действий участников стратегического планирования на всех уровнях государственного управления в достижении стратегических приоритетов»; 
- «цифровая аналитическая платформа для представления статистических данных» ;

- «Единая государственная платформа сбора данных промышленного интернета вещей и инструментов анализа объективных данных о наблюдаемых объектах на основе утвержденных ведомственных моделей данных в составе Платформы исполнения государственных функций»;

- «Платформа исполнения государственных функций, в том числе при осуществлении контрольной (надзорной) деятельности, включающая создание, развитие и функционирование единого реестра обязательных требований типового облачного решения по автоматизации контрольной (надзорной) деятельности, в целях обеспечения управления деятельностью сотрудников государственных органов»;

- «платформа "Цифровое строительство"»;

- «цифровая платформа для процесса осуществления внешнего государственного аудита (контроля)»;

- «цифровая платформа “Образование в РФ для иностранцев"»;

- «облачная цифровая платформа обеспечения оказания государственных (муниципальных) услуг и сервисов, в том числе в электронном виде»;

- «цифровая платформа АИС Ростехнадзора»;

- «образовательная платформа» (говорится во множественном числе).

Перечисленными в Паспорте 2019 г. цифровыми платформами дело не заканчивается - упоминания об отдельных видах платформ содержат и иные документы 2019 г., в частности:

- Стратегия развития здравоохранения в Российской Федерации на период до 2025 года ${ }^{2}$ указывает на «централизованные цифровые платформы в целях диагностики заболеваний, в том числе с использованием искусственного интеллекта»;

Долгосрочная стратегия развития зернового комплекса Российской Федерации до 2035 года ${ }^{3}$ упоминает «цифровые платформы учета земель сельскохозяйственного назначения, мониторинга агропромышленного комплекса, прослеживаемости производимой агропромышленным комплексом продукции» и «платформы мониторинга,

1 В развитие соответствующего положения была принята Концепция создания цифровой аналитической платформы предоставления статистических данных, утв. распоряжением Правительства Российской Федерации от 17 декабря 2019 г. № 3074-р.

2 Утверждена Указом Президента РФ от 6 июня 2019 г. № 254.

3 Утверждена распоряжением Правительства РФ от 10 августа 2019 г. № 1796-р. 
прослеживаемости, прогнозирования, управления процессами и государственной поддержки агропромышленного комплекса»;

- Стратегия развития экспорта услуг до 2025 года ${ }^{1}$ упоминает «онлайновые цифровые платформы»;

- Основные направления развития Государственной автоматизированной системы Российской Федерации «Выборы» до 2022 года $^{2}$ указывают на необходимость создания цифровой платформы, «которая после завершения ее создания и ввода в эксплуатацию будет являться новой версией ГАС "Выборы"»";

- в Послании Президента РФ Федеральному Собранию от 20 февраля 2019 г. было указано на необходимость создания специальной цифровой платформы, с помощью которой предприниматели смогут не только сделать публичной информацию о давлении на бизнес и добиться рассмотрения вопроса по существу. В поручении Президента РФ по реализации указанного положения в Послании ${ }^{4}$ данная платформа имеет название «цифровая платформа для приема обращений субъектов предпринимательской деятельности в связи с оказанием на них давления со стороны правоохранительных органов», а в постановлении Правительства РФ от 27 декабря 2019 г. № 1894 «Об утверждении Правил предоставления из федерального бюджета субсидии в виде имущественного взноса в автономную некоммерческую организацию "Платформа для работы с обращениями предпринимателей"» указано название данной платформы - «платформа для работы с обращениями предпринимателей»;

- Федеральным законом от 2 августа 2019 г. № 259-Ф3 «0 привлечении инвестиций с использованием инвестиционных платформ и о внесении изменений в отдельные законодательные акты Российской Федерации» было введено понятие (ст. 2) «инвестиционная платформа».

Теперь посмотрим на определения различных видов платформ, которые появились в 2019 г.

1 Утверждена распоряжением Правительства РФ от 14 августа 2019 г. № 1797-р.

2 Утверждены постановлением ЦИК России от 30 октября 2019 г. № 231/1727-7.

3 Такая система будет учитывать опыт электронного голосования, имеющийся как в России, так и за рубежом (см., к примеру: Алексеев Р. А., Абрамов А. В. Проблемы и перспективы применения электронного голосования и технологии избирательного блокчейна в России и за рубежом // Гражданин. Выборы. Власть. 2020. № 1(15). С. 9-21; Федоров В.И. Проекты по автоматизации голосования в исторической ретроспективе // Гражданин. Выборы. Власть. 2020. № 1(15). С. 34-55 и ряд иных работ).

${ }^{4}$ Перечень поручений по реализации Послания Президента Федеральному Собранию утвержден Президентом РФ 27 февраля 2019 г. № Пр-294. 
Самое простое из них (и не прямое) дается в Правилах предоставления из федерального бюджета субсидии в виде имущественного взноса в автономную некоммерческую организацию «Платформа для работы с обращениями предпринимателей» ${ }^{1}$ - «организационноинформационная система»².

Остается лишь догадываться, что имели в виду разработчики документа под такой системой: ни в одном ином нормативном акте о ней не сказано ни слова.

Статья 2 Федерального закона от 2 августа 2019 г. № 259-Ф3 «0 привлечении инвестиций с использованием инвестиционных платформ и о внесении изменений в отдельные законодательные акты Российской Федерации» дает такое определение понятия «инвестиционная платформа»: «информационная система в информационно-телекоммуникационной сети “Интернет", используемая для заключения с помощью информационных технологий и технических средств этой информационной системы договоров инвестирования, доступ к которой предоставляется оператором инвестиционной платформы».

Таким образом, определение инвестиционной платформы «завязано» на другом понятии - «информационная система», которое (в отличие от предыдущего понятия - «организационно-информационная система») определено Федеральным законом от 27 июля 2006 г. № 149-Ф3 «Об информации, информационных технологиях и о защите информации» (ст. 2). В нем под такой системой понимается «совокупность содержащейся в базах данных информации и обеспечивающих ее обработку информационных технологий и технических средств».

Говоря иначе, инвестиционная платформа - это информаџия, содержащаяся в базах данных, а также технологии и технические средства, позволяющие взаимодействовать инвестору и лицу, привлекающему инвестиции, совершать юридически значимые действия, и главное - заключать договоры инвестирования.

На первый взгляд, перед нами определение, которое гораздо шире приведенного выше определения агрегатора информации о товаpax (услугах), поскольку включает три составляющие - информацию, технологии и технические средства.

1 Утверждены постановлением Правительства РФ от 27 декабря 2019 г. № 1894.

2 Вот фрагмент соответствующего текста: «...продвижение организационноинформационной системы (платформы) поддержки совместной деятельности организаций и органов государственной власти, направленной на улучшение условий ведения предпринимательской деятельности...». 
Однако в Федеральном законе от 2 августа 2019 г. № 259-Ф3 отсутствуют требования к технологиям и средствам. Строго говоря, назвать платформой можно (с определенными оговорками) любую совокупность информации, технологий и средств, а учитывая, что взаимодействие оператора инвестиционной платформы и других лиц выстраивается через сайт (страницу сайта) в сети Интернет, то мы опять приходим к тому, что инвестиционная платформа - это, по существу и главным образом, тоже сайт (страница сайта). На этот вывод наталкивает и само определение - «информационная система в информационно-телекоммуникационной сети “Интернет"...».

Таким образом, становится очень сложно отличить регулируемую деятельность от нерегулируемой. В результате данный закон не позволяет в полном объеме охватить взаимодействие потенциальных инвесторов и лиц, привлекающих инвестиции, с использованием сети Интернет. Этот закон изначально планировался как закон о краудфандинге (и по привычке его так и называют). В реальности никаким законом о краудфандинге он не является, поскольку не только не покрывает безвозмездный краудфандинг, но не покрывает даже инвестирование через интернет-сервисы ${ }^{1}$. Ничто не мешает придумать такой сервис, который, по существу, будет аналогичен описанному в Федеральном законе от 2 августа 2019 г. № 259-Ф3, но не будет подпадать под его действие. Статья 25 данного закона указывает, что осуществление деятельности по организации привлечения инвестиций с использованием инвестиционных платформ после дня вступления его в силу допускается лицами, сведения о которых включены в реестр операторов инвестиционных платформ. Но если мы, предположим, назовем свой сервис не платформой, а просто сайтом для взаимодействия и будем инвестировать иными способами, кроме предусмотренных этим законом, то мы уже выйдем из его поля². Следовательно, деятельность разного рода лиц по привлечению через Интернет финансовых ресурсов вне рамок этого закона вполне возможна, а значит, и риски для «инвесторов» (кавычки здесь уместны напомню, что и обладатели билетов МММ тоже считали себя инвесторами) весьма велики.

То, что определение инвестиционной платформы в Федеральном законе от 2 августа 2019 г. № 259-Ф3 недоработано, показывают и

${ }^{1}$ См.: Габов А. В., Хаванова И. А. Краудфандинг: законодательное оформление webмодели финансирования в контексте правовой доктрины и зарубежного опыта // Вестник Пермского университета. Юридические науки. 2020. Вып. 47. С. 28-44. C. 11-20.

2 Подробнее см.: Габов А. В. Правовое регулирование краудфандинга в России.... 
«спрятанные» в его тексте технические понятия, показывающие, что платформа имеет определенное строение, уяснить которое через такие понятия не в полной мере возможно. К примеру, статья 11 данного закона использует понятие «узлы инвестиционной платформы». Конкретного определения этих узлов нет, но из данной статьи можно понять, что «узлы инвестиционной платформы» - это технические средства инвестиционной платформы, физически отделенные друг от друга и подключенные к информационно-телекоммуникационной сети, на которых хранится база данных инвестиционной платформы.

Пример с определением инвестиционной платформы показывает риски, вызванные отсутствием представления о сущности цифровой платформы в нашем праве: как только идеи о развитии платформ, заложенные в различного рода программах и стратегиях, попытались перенести в правовые решения, которые порождают вертикальные отношения регулирования, так тут же вскрылось, что без внятного определения платформы и установления ее отличий от сходных явлений государственное регулирующее воздействие может быть неэффективным.

Третье определение и объяснение цифровой платформы в документах 2019 г. мы встречаем в Концепции создания цифровой аналитической платформы предоставления статистических данных ${ }^{1}$.

Согласно указанному документу, «платформа - это совокупность организационных, методологических, правовых мероприятий и информационных решений, обеспечивающих непрерывную автоматизацию процессов статистического производства и позволяющих максимально снизить отчетную нагрузку на респондентов, сделать процесс сбора данных "незаметным" и необременительным для бизнеса и населения, а процесс распространения статистики - удобным для всех категорий пользователей и удовлетворяющим растущий спрос на информацию».

Оценивая данное определение, отметим следующее:

- оно очень неконкретно; если в двух предыдущих определениях есть ключевое слово-маркер - «информационная система» (хотя в первом случае и в неявном виде), т. е. мы видим «привязку» определения к базовым законам в сфере информационного права, то в этом случае никакого определенного слова-маркера нет - ни «мероприятия», ни «решения» ими не являются;

1 Утверждена распоряжением Правительства Российской Федерации от 17 декабря 2019 г. № 3074-p. 
- из определения видна попытка охватить необъятное; при этом понятно, что его авторы ориентировались на самом деле на создание интерактивного сервиса обмена субъектами, обязанными предоставлять статистические данные и субъектом, их собирающим, - с тем, чтобы действия в рамках этого обмена имели юридическое значение. Скорее всего, перед нами цифровизация функции, перевод ее в онлайн-формат, но не более того.

Еще одно определение можно встретить в Правилах предоставления субсидий российским организациям на возмещение части затрат на разработку цифровых платформ и программных продуктов в целях создания и (или) развития производства высокотехнологичной промышленной продукции ${ }^{1}$. В этом документе под «цифровой платформой» понимается совокупность информационных технологий и технических средств, обеспечивающих решение определенных технологических задач (их перечень из текста неясен) и взаимодействие субъектов хозяйственной деятельности в сфере промышленности. Это определение нельзя назвать в полной мере ясным, ибо «совокупность» как одно из ключевых слов-маркеров ничего не поясняет о природе явления.

В 2019 г. для целей описания досудебного порядка разрешения споров, возникающих из потребительских отношений, появляется понятие «онлайн-платформа» (в проекте федерального закона «0 внесении изменений в Закон Российской Федерации “О защите прав потребителей”» и Федеральный закон «“Об альтернативной процедуре урегулирования споров с участием посредника (процедуре медиации)" в части создания правовой основы для развития системы альтернативных онлайн-механизмов урегулирования споров» ${ }^{2}$ ).

Интересно, что ни Программа 2017 г., ни Паспорта 2018 и 2019 гг. не предусматривали появления соответствующей платформы. Не предусматривалось ее появление и иным документом, положенным в основание разработки соответствующего проекта - перечнем поручений Президента Российской Федерации от 25 мая 2017 г. № Пр$1004 \Gamma \mathrm{C}^{3}$.

Согласно проекту (в его первоначальной редакции) «платформа онлайн-урегулирования споров» определялась как «информационная система, включающая сайт в информационно-телекоммуникационной

1 Утверждено постановлением Правительства РФ от 30 апреля 2019 г. № 529.

2 ID проекта: 01/05/05-19/00091641. Тест доступен на следующем информационном pecypce: URL: https://regulation.gov.ru/projects\#npa=91641 (дата обращения: 12.12.2020).

${ }^{3}$ Им поручалось сформировать систему досудебного урегулирования споров по вопросам защиты прав потребителей. 
сети “Интернет” и (или) программу для электронных вычислительных машин, обеспечивающая с использованием информационнотелекоммуникационной сети “Интернет” процесс досудебного урегулирования споров между потребителем и изготовителем (исполнителем, продавцом, уполномоченной организацией или уполномоченным индивидуальным предпринимателем, импортером, владельцем агрегатора) при продаже товаров (выполнении работ, оказании услуг)...».

Следует обратить внимание на особенности этого определения: словом-маркером, как и в случае с определением инвестиционной платформы Федеральным законом от 2 августа 2019 г. № 259-Ф3, была информационная система, однако разработчики данного определения, по существу, взяли лишь усеченный вариант определения информационной системы, сведя ее к сайту (программе для ЭВМ), как в случае с определением агрегатора.

При последующем обсуждении и терминология, и определение изменились: стало использоваться понятие «онлайн-платформа», которую предложили определить следующим образом: «электронный сервис в государственной информационной системе - “Единый портал государственных и муниципальных услуг (функций)”, обеспечивающий процесс предъявления, рассмотрения и удовлетворения требований потребителей...».

2019 год показал, что идея платформ прочно вошла и в обиход юристов. Это хорошо видно из Концепции информатизации судов и системы Судебного департамента до 2030 г., утвержденной постановлением Президиума Совета судей Российской Федерации от 2 декабря 2019 г. № $785^{1}$.

Заканчивая обзор документов 2019 г., нельзя не указать на примеры того, как в различных официальных документах появлялись указания на иные (кроме цифровых) платформы, т. е. продолжалось бессистемное применение специальной терминологии, образованной с использованием слова «платформа». В частности:

- в Государственной программе «Научно-технологическое развитие Российской Федерации» 2 упоминаются «прогнозно-аналитические платформы» и «платформа университета Национальной технологической инициативы»; «интеграционная платформа непрерывного образования и набора сервисов, обеспечивающих навигацию и под-

${ }^{1}$ См.: Капустин О.А. Приоритетные направления организации судебной деятельности на современном этапе // Администратор суда. 2020. № 2. С. 3-9; Бурдина Е.В. Цифровизация судебной деятельности: направления, прогнозы и риски // Администратор суда. 2020. № 2. С. 10-14.

2 Утверждена постановлением Правительства РФ от 29 марта 2019 г. № 377. 
держку граждан при выборе образовательных программ и организаций, осуществляющих образовательную деятельность»;

- Федеральная научно-техническая программа развития генетических технологий на 2019-2027 годы ${ }^{1}$ содержит упоминание о «векторных платформах на основе рекомбинантных вирусов» и «универсальных платформенных решениях для быстрого создания вакцин»;

- в Национальной стратегии развития искусственного интеллекта на период до 2030 года ${ }^{2}$ упоминаются «общедоступные платформыІ»;

- Стратегия развития судостроительной промышленности на период до 2035 года ${ }^{3}$ содержит указание на «информационную платформу по выявлению, инвентаризации, классификации, экспертизе, постановке на учет, а также уступке и передаче прав на результаты интеллектуальной деятельности».

11. В 2020 г. увеличились и количество документов, в которых упоминаются «цифровые платформы», и перечень видов цифровых платформ, и их определения.

Федеральный закон от 20 июля 2020 г. № 211-Ф3 «0 совершении финансовых сделок с использованием финансовой платформы» ввел понятие «финансовая платформа», определив его следующим образом (ст. 2): «информационная система, которая обеспечивает взаимодействие финансовых организаций или эмитентов с потребителями финансовых услуг... посредством информационно-телекоммуникационной сети “Интернет" в целях обеспечения возможности совершения финансовых сделок и доступ к которой предоставляется оператором финансовой платформы».

Оценивая данное определение, отметим, что оно построено по модели (даже несмотря на некоторые отличия) определения инвестиционной платформы, данного в статье 2 Федерального закона от 2 августа 2019 г. № 259-Ф3; соответственно в части его «привязок» можно высказать те же замечания, что и выше в отношении определения инвестиционной платформы.

Однако между двумя законами имеется и некоторая разница в тексте в части т. н. «узлов информационной системы». В Федеральном законе от 20 июля 2020 г. № 211-ФЗ под ними понимаются «пользователи информационной системы на основе распределенного реестра, обеспечивающие тождественность информации, содержащейся в ука-

1 Утверждена постановлением Правительства РФ от 22 апреля 2019 г. № 479.

2 Утверждена Указом Президента РФ от 10 октября 2019 г. № 490 «0 развитии искусственного интеллекта в Российской Федерации».

3 Утверждена распоряжением Правительства РФ от 28 октября 2019 г. № 2553-р. 
занной информационной системе, с использованием процедур подтверждения действительности вносимых в нее (изменяемых в ней) записей».

Хорошо заметна разница в определении «узлов»: в части инвестиционных платформ узлы - это «средства» (т. е. объекты), а в части финансовой платформы это «пользователи» (т. е. субъекты).

В Постановлении Правительства РФ от 12 октября 2020 г. № 1674 «0 проведении эксперимента по созданию, переводу и развитию государственных информационных систем и их компонентов на единой цифровой платформе Российской Федерации "ГосТех" вводится понятие «единая цифровая платформа Российской Федерации "ГосТех"», или «платформа "ГосТех"». Как было видно ранее, различные документы указывали на «государственную единую облачную платформу»; насколько эти феномены совпадают по своим существенным характеристикам, не вполне ясно.

В Положении о проведении эксперимента по созданию, переводу и развитию государственных информационных систем и их компонентов на единой цифровой платформе Российской Федерации «ГосТех», утвержденном указанным постановлением Правительства РФ, дано такое определение «единой цифровой платформе Российской Федерации «ГосТех» («платформе "ГосТех"»): «экосистема создания, развития и эксплуатации государственных информационных систем, включающая в себя единую программно-аппаратную среду и методологию, поддерживающая взаимоотношения граждан, государственных органов и коммерческих организаций на базе современных информационных технологий с целью повышения доступности государственных услуг и функций, а также направленная на снижение расходов участников на использование государственных услуг». Помимо этого, выделено еще одно определение - «платформы разработки»: «программно-аппаратная среда, предоставляющая функционально полный набор информационно-технологических сервисов, позволяющих эффективно создавать, развивать и эксплуатировать прикладное программное обеспечение государственных информационных систем и их компонентов».

Первое из указанных определений как минимум необычно по сравнению с ранее использованными определениями цифровой платформы: в нем словом-маркером является «экосистема создания, развития и эксплуатации государственных информационных систем».

Не в полной мере ясно, что это за понятие. До этого у нас имелись два определения экосистемы: 
- Стратегия развития информационного общества в Российской Федерации на 2017-2030 годы определила понятие «экосистема цифровой экономики» как «партнерство организаций, обеспечивающее постоянное взаимодействие принадлежащих им технологических платформ, прикладных интернет-сервисов, аналитических систем, информационных систем органов государственной власти Российской Федерации, организаций и граждан»;

- Основные направления реализации цифровой повестки Евразийского экономического союза до 2025 года определили понятие «цифровая экосистема». Это «открытая устойчивая система, включающая субъекты цифровой экосистемы (физические, юридические, виртуальные и пр.), а также связи и отношения этих субъектов в цифровой форме на основе сервисов цифровой платформы».

Хорошо видно, что даже между этими определениями есть разница (и значительная), а уж как при такой ситуации использовать слово «экосистема» как слово-маркер для определения вида цифровой платформы - неясно.

Стратегия развития Арктической зоны Российской Федерации и обеспечения национальной безопасности на период до 2035 года ${ }^{1}$ упоминает «цифровую платформу, предназначенную для безбумажного оформления мультимодальных перевозок пассажиров и грузов» как основу для объединения транспортно-логистических услуг, оказываемых в акватории Северного морского пути.

В 2020 г. появился очень интересный документ - Общенациональный план действий, обеспечивающих восстановление занятости и доходов населения, рост экономики и долгосрочные структурные изменения в экономике 2 .

Он содержит отдельный раздел (6.1) с очень претенциозным названием - «Государство как цифровая платформа». Сама идея государства как платформы не нова, и она не российская ${ }^{3}$ что эта идея означает для развития общественных отношений, в точности не ясно, поскольку никакого объяснения ее нет; можно предположить (в том числе исходя из анализа содержания документа), что данный политико-правовой посыл означает как минимум ускоренную цифровизацию всего комплекса взаимоотношений между государственными органа-

1 Утверждена Указом Президента РФ от 26 октября 2020 г. № 645.

2 Одобрен на заседании Правительства РФ 23 сентября 2020 г. (протокол № 36, раздел VII) № П13-60855 от 2 октября 2020 г.

${ }^{3}$ См.: Стырин Е. М., Дмитриева Н. Е., Синятуллина Л.Х. Государственные цифровые платформы: от концепта к реализации // Вопросы государственного и муниципального управления. 2019. № 4. С. 34-35. 
ми и «внешним миром» (гражданами и организациями) и взаимоотношений между государственными органами и внутри них, в том числе полный перевод взаимодействия субъектов в отдельных сферах на «электронный формат взаимодействия».

Применительно к указанному документу идея государства как цифровой платформы раскрывается через конкретные задачи по ускорению введения цифровых технологий в экономике, в том числе и путем создания специальных цифровых платформ:

- «цифровой платформы в рамках инфраструктуры электронного правительства для обмена данными между гражданами и организациями в электронном виде с их согласия, в том числе для оказания финансовых услуг и сервисов»;

- «платформы для подписания усиленной неквалифицированной подписью договоров между физическими и юридическими лицами, трудовых соглашений, за исключением сделок с недвижимым имуществом» (на базе единого портала государственных и муниципальных услуг (функций);

- «единой цифровой платформы ведения и акцептования оферт с использованием инфраструктуры электронного правительства»;

- «платформы на Едином портале государственных и мунищипальных услуг (функций) для выдачи любых лищензий и разрешений для бизнеса с обеспечением возможности электронной подачи заявлений без необходимости очных обращений»;

- «цифровой платформы лесного хозяйства».

В 2020 г. были даны поручения Президента РФ, в которых указывалось на создание (развитие) каких-то отдельных цифровых платформ и/или упоминались платформы (с использованием понятийсинонимов - «информационная платформа» и «интернет-платформа»). Таких поручений было минимум девять:

- Пр-469, п. 2 (из Перечня поручений по вопросам реализации Концепции государственной миграционной политики на 20192025 годы ${ }^{1}$;

- Пр-354, п. 1 8)-2; Пр-354, п. 1 8)-3; Пр-354, п. 3; Пр-354, п. 12 3) (из Перечня поручений по итогам заседания Совета по развитию местного самоуправления 30 января 2020 г.) ${ }^{2}$;

${ }^{1}$ Cм.: URL: http://www.kremlin.ru/acts/assignments/orders/62960 (дата обращения: 22.12.2020).

${ }^{2}$ Cм.: URL: http://www.kremlin.ru/acts/assignments/orders/62919 (дата обращения: 22.12.2020). 
- Пр-645, п. 1 3) (из Перечня поручений по итогам встречи с представителями предпринимательского сообщества, состоявшейся 26 марта 2020 г.) ${ }^{1}$;

- Пр-930, п. 1 е-2 (из Перечня поручений по итогам совещания о ситуации на рынке труда, состоявшегося 27 мая 2020 г. $)^{2}$;

- Пр-1726ГС, п. 7 в) (из Перечня поручений по итогам расширенного заседания президиума Государственного совета, состоявшегося 28 сентября 2020 г.) ${ }^{3}$;

- Пр-2177, п. 4 в (из Перечня поручений по итогам пленарного заседания форума АСИ, состоявшегося 13 ноября 2020 г.) ${ }^{4}$.

К платформам, создание (развитие) которых предусматривалось указанными поручениями, можно отнести следующие (число (множественное или единственное) здесь будет такое, как оно использовано в соответствующем поручении):

- информационные платформы для онлайн-образования;

- цифровая платформа, ориентированная на поддержку производственной и сбытовой деятельности субъектов малого и среднего предпринимательства (в том числе индивидуальных предпринимателей);

- интернет-платформа «Конструкториум»;

единая информационная платформа, обеспечивающая для граждан и организаций возможность размещения и поиска предложений в сфере занятости (в том числе оработе временного характера) и оформления соответствующих правоотношений;

- единая цифровая платформа, функционирующая по принципу «одного окна» и располагающая механизмом обратной связи, для рассмотрения обращений граждан, поступающих в электронной форме;

- единая цифровая платформа, располагающая механизмом обратной связи (в сфере общественных связей и коммуникаций);

- единая цифровая платформа, предоставляющая возможность направления гражданами предложений по повестке дня общего собрания собственников помещений в многоквартирных домах в электронной форме и голосования по ним.

${ }^{1}$ Cм.: URL: http://www.kremlin.ru/acts/assignments/orders/63192 (дата обращения: 22.12.2020).

${ }^{2}$ Cм.: URL: http://www.kremlin.ru/acts/assignments/orders/63478 (дата обращения: 22.12.2020).

${ }^{3}$ Cм.: URL: http://www.kremlin.ru/acts/assignments/orders/64273 (дата обращения: 22.12.2020).

${ }^{4}$ Cм.: URL: http://www.kremlin.ru/acts/assignments/orders/64694 (дата обращения: 22.12.2020). 
12. Анализируя немалый массив различных официальных документов (программных, концептуальных, стратегических, нормативных), в которых развивается тема цифровых платформ, так и хочется сказать словами из названия книги Олдоса Хаксли «A New Brave World», ибо складывается ощущение полной и тотальной платформизации (как минимум в качестве перспективы) всех элементов социальной жизни.

Меняется и язык официальных документов и сообщений; масштаб новояза (с использованием слова «платформа») становится таким, что понять реальный смысл многих тезисов может только лицо, имеющее специальные познания. Вот, к примеру, заголовок (всего лишь) одного информационного сообщения на сайте Банка России: «Второй пилотной платформой по ипотеке в проекте "Маркетплейс" Банка России станет “Жилищная экосистема ВТБ”. Это позволит сделать процесс заключения договора ипотечного кредитования $\underline{\partial u c-}$ танционным, быстрым и надежным». Мы специально подчеркнули несколько слов-маркеров. Даже их достаточно, чтобы сказать: обычный рядовой гражданин едва ли поймет, о чем этот текст.

О влиянии платформизации на социальную жизнь мы поговорим далее, здесь же подведем некоторые итоги (неутешительные) проведенного анализа нормативного материала:

а) как и в доцифровую эпоху, в официальных документах (аналогичная картина в исследованиях), которые направлены на развитие цифровой экономики (или ее касаются), наблюдается полное пренебрежение аккуратностью в использовании терминологии ${ }^{2}$. Даже само понятие «цифровая платформа» не является единым и устоявшимся. К примеру, используют его аналоги - «онлайн-платформа» или «интернет-платформа»; иногда встречается и такой гибрид, как «цифровая онлайн-платформа»;

${ }^{1}$ CM.: URL: http://www.cbr.ru/press/event/?id=5270\#highlight=\%D0\%BF\%D0\%BB\% D0\%B0\%D1\%82\%D1\%84\%D0\%BE\%D1\%80\%D0\%BC\%D0\%B0\%7C\%D0\%BF\%D0\%BB\%D 0\%B0\%D1\%82\%D1\%84\%D0\%BE\%D1\%80\%D0\%BC\%D0\%BE\%D0\%B9 (дата обращения: 28.11.2020).

2 Отметим, что для информационного права (а именно к этой отрасли сильно «привязан» исследуемый вопрос) это давняя проблема, хорошо осознаваемая исследователями; понятны им и ее основы - некритичный перевод с иностранного, заимствование терминологии из других сфер и сленгов и проч. (см.: Мардер Н. С. О терминологии в законодательстве об информационных технологиях // Понятийный аппарат в информационном праве: колл. монография / отв. ред. И.Л. Бачило, Т.А. Полякова, В.Б. Наумов. М.: ИГП РАН. Издательство «Канон+» РООИ «Реабилитация, 2017. С. 255256). Однако никакого положительного влияния на позитивное право это осознание (понимание) не имеет. 
б) определения «цифровой платформы» или «онлайн-платформы» не выработано ${ }^{1}$, и не видно даже предпосылок для его появления.

Нормативные документы, различного рода программы, концепции и доклады упоминают такие явления, как «агрегаторы» («агрегатор информации о товарах (услугах)», «платежный агрегатор», «новостной агрегатор», «единый агрегатор торговли» ${ }^{2}$ ) и «маркетплейсы», то относя их к платформам, то квалифицируя как самостоятельные феномены; в 2020 г. введено еще одно новое понятие - «суперсервис» ${ }^{3}$.

Отдельно стоит отметить сохранение в нормативных актах понятий, которые описывают отдельные элементы дистанционного взаимодействия, функции которых охватываются (могут частично охватываться) понятием «цифровая платформа», например: «портал» ${ }^{4}$, «интернет-портал», «веб-портал» ${ }^{6}$, «информационно-аналитическая система» ${ }^{7}$ и ряд других (к примеру, отдельный разговор о государственной информационной системе).

По существу, разграничить формы дистанционного взаимодействия (с различными целями, узким или широким функционалом (воз-

1 Этот вывод касается нормативных, концептуальных, программных документов, документов стратегического планирования, а также доктрины (см. далее), хотя осознание критичности наличия такого определения можно увидеть в отдельных работах. К примеру, авторы одной из профильных монографий, вышедших в 2019 г., указывали, что «определение юридического понятия цифровой платформы» относится к одной из первоочередных задач по разработке доктринальных подходов и их законодательного закрепления в сфере цифровой экономики (см.: Цифровая экономика: проблемы правового регулирования: монография / отв. ред. В. В. Зайцев, О. А. Серова. М.: КНОРУС, 2019. C. 23).

2 В Решении ФАС России по делу № 11/01/10-41/2019 (дело «Booking. com»), упоминаются еще и «агрегаторы агрегаторов», под которым, как разъясняется в документе понимаются «сайты, собирающие информацию с других сайтов-агрегаторов и представляющие ее потребителю в удобной форме» (cм.: URL: https://br. fas.gov.ru/ca/upravlenie-po-kontrolyu-za-gosudarstvennymi-i-munitsipalnymi-informatsionnymi-sistema-

mi/cdf15018-ef29-40e8-acbd-d39edc8aee39/?query=booking.com (дата обращения 09.02.2021).

${ }^{3}$ См.: постановление Правительства РФ от 31 декабря 2020 г. № 2427 «0 функционировании суперсервиса “Поступление в вуз онлайн”».

${ }^{4}$ См., к примеру: ст. 241.2 Бюджетного кодекса РФ.

${ }^{5}$ См., к примеру: указ Президента РФ от 2 апреля 2014 г. № 198 «0 порядке опубликования законов и иных правовых актов субъектов Российской Федерации на “Официальном интернет-портале правовой информации" (www.pravo.gov.ru)».

${ }^{6}$ См., к примеру: протокол о порядке регулирования закупок (Приложение № 25 к Договору о Евразийском экономическом союзе (Астана, 29 мая 2014 года)).

${ }^{7}$ См.: ст. 16.2 Закона РФ от 19 апреля 1991 г. № 1032-1 «0 занятости населения в Российской Федерации». 
можностями, пользователями), наличием/отсутствием интерактивности и проч.), которые охватываются понятием «цифровая платформа», с другими формами такого взаимодействия, которые под понятие «цифровая платформа» не подпадают, - нельзя.

Этого не позволяют сделать ни нормативные, концептуальные и стратегические документы, ни результаты соответствующих научных исследований.

«Сущность» цифровой платформы отечественным правом на сегодняшний день не «поймана»; в большинстве случаев ее использование - это то, что на современном молодежном сленге называют «хайп»;

в) слово «платформа» продолжает служить для появления новых правовых понятий, с цифровой экономикой не связанных; при этом не видно никакой рефлексии в части такого явления, как «технологическая платформа»;

г) в официальных документах упоминается множество различных видов цифровых платформ, делаются попытки дать определение отдельным платформам, при этом никаких единых подходов к таким определениям нет.

Для конструирования определений используются разные словамаркеры («привязывающие» определение к другому понятию, уже данному в каком-то законе или ином нормативном правовом акте), а иногда и просто слова, которые не имеют в праве какого-то специального значения («мероприятия», «совокупность»);

д) введение новых видов платформ не сопровождается рефлексией в части видов платформ, ранее предусмотренных официальными документами; в результате получается нагромождение видов платформ; непонятно, какова их конфигурация (о системе вообще говорить не приходится);

е) следует обратить внимание на появление такого понятия, как «платформенное решение», которым в официальных документах также начинают едва ли не злоупотреблять (как и в случае с платформами); это понятие не имеет легального определения;

ж) при указании на конкретные виды платформ имеется значительная пестрота в использовании их качественных характеристик: «единая», «аналитическая», «универсальная», «отечественная», «пилотная», «кросс-отраслевая», «прорывная», «перспективная», «сквозная» и др.

Использование соответствующего прилагательного должно не просто придавать определенную качественную характеристику, но, 
с нашей точки зрения, иметь вполне ясные и определенные правовые последствия:

- вектор регулирования,

- предопределение содержания правовых и технических решений, которые будут приниматься для создания нормативного регулирования в части платформы конкретного вида (например, использование только отечественного программного обеспечения и оборудования),

- презюмирование определенного соотношения правовых средств при регулировании (запретов, обязываний и дозволений),

- презюмирование широкого использования правовых стимулов и Т. Д.

В реальности ничего подобного по результатам анализа мы не видим;

3) отсутствует ясность в классификациях платформ; абсолютное большинство упоминаемых видов платформ не имеют отношения к сфере оборота товаров, работ и услуг в процессе осуществления различной экономической деятельности, они в основном предназначены для информационного взаимодействия субъектов (внутри системы государственного управления или для взаимодействия субъектов государственного управления и граждан) ${ }^{1}$;

и) из анализа видно, что одни платформы (создаваемые или планируемые) локальны, вторые рассчитаны на неограниченный круг лиц.

В экономической литературе о платформах рассуждают с точки зрения наличия сетевого эффекта (см. ниже), тогда как деятельность целого ряда платформ подобного эффекта иметь не будет: эти платформы рассчитаны на ограниченный, а иногда и заранее определенный закрытый круг лиц (например, при инвестировании с использованием инвестиционной платформы путем предоставления займов ${ }^{2}$ );

к) на фоне множества действующих цифровых платформ, а также планов по увеличению их числа, в том числе в части взаимодействия граждан и государства, отсутствует (не сформирована) единая цифровая среда доверия, что сильно снижает эффективность планов по широкому использованию платформ. В результате вся платформизация пока выглядит как броуновское движение, имеющее ограниченный результат.

1 Это любопытный вывод. Дело в том, что в исследованиях отмечается, что «в большинстве случаев применение цифровых платформ преследует коммерческие цели» (см.: Карихия А. А. Гражданско-правовая модель регулирования цифровых технологий... С. 205; Он же. Цифровые технологические (онлайн) платформы: российский и зарубежный опыт регулирования // Гражданское право. 2019. № 3. С. 25). Однако для отечественного цифрового развития этот вывод, как видно, требует некоторых оговорок.

${ }^{2}$ См.: Габов А.В. Правовое регулирование краудфандинга в России... С. 72-73. 
Сущность цифровой платформы в экономических

и правовых исследованиях; функции и виды платформ

13. Выводы, сделанные в предыдущем разделе, могут показаться излишне пессимистичными, однако стоит заметить, что в данном случае отечественная правовая система не слишком отличается от общемировых трендов. И причина тому проста: самой теме платформ не так много лет.

Слово «платформа» (platform) вошло в экономические и правовые исследования ${ }^{1}$, а также в обиход представителей бизнес-сообщества 2000 -х гг. как результат развития бизнеса, основанного на почти повсеместном распространении компьютеров и других технических устройств, обеспечивающих возможность выхода в Интернет и использования специальных компьютерных программ (которые в российском праве именуются «программы для ЭВМ»).

Именно представители этого бизнеса (цифровые посредники) стали, как показывают исследования, называть новые возможности, которые они предлагали своим пользователям (клиентам), и средства, которые такие возможности давали, платформойㄹ․

Новизну явления подчеркивают исследователи. Tarleton Gillespie в 2010 г. указывал на соответствующие заявления представителей этого нового бизнеса так: «Термин “платформа" появился в последнее время как все более привычный термин в описании онлайн-сервисов контент-посредников, как в их самохарактеристиках, так и в более широком публичном дискурсе пользователей, прессы и комментаторов» ${ }^{3}$. Howard A. Shelanski в работе 2013 г. ${ }^{1}$ пишет, что и коммерческий

${ }^{1}$ Как отмечается в работах по экономике, научные основы исследований в области многосторонних платформ были заложены в начале 2000-х гг. в работах исследователей из США и Западной Европы (см.: Яблонский С.A. Многосторонние платформы и рынки: основные подходы, концепции и практики // Российский журнал менеджмента. 2013. № 4. С. 58). К примеру, к числу таких работ можно отнести: Rochet J.-C., Tirole J. Platform competition in two-sided markets // Journal of European Economic Association. 2003. № 1 (4). P. 990-1029. URL: https://www.rchss.sinica.edu.tw/cibs/pdf/RochetTirole3.pdf (дата обращения: 19.12. 2020); Evans D.S., Hagiu A., Schmalensee R. Invisible Engines: How Software Platforms Drive Innovation and Transform Industries. The MIT Press, 2006 и др.

2 Cм.: Gillespie T. The Politics of "Platforms" // New Media \& Society. 2010. Vol. 12. Issue 3. URL: https://www.researchgate.net/publication/258173728_The_politics_of_'platforms' (дата обращения: 15.12.2020).

3 «The term 'platform' has emerged recently as an increasingly familiar term in the description of the online services of content intermediaries, both in their self-characterizations and in the broader public discourse of users, the press, and commentators» (cm.: Gillespie, Tarleton. Op. cit.). 
Интернет - это все еще относительно недавнее явление, некоторым из наиболее важных цифровых платформ (Facebook и Twitter) менее десяти лет, а другие игроки (Google, Yahoo, Amazon) существует и еще меньше $\mathrm{e}^{2}$. В похожей логике о новизне платформы как предмета дискурса пишет К. Шваб в работе 2016 г.: «0 широко известных сегодня дизруптивных платформах Airbnb, Uber, Alibaba мало кто имел представление всего несколько лет назад» ${ }^{3}$.

Tarleton Gillespie отмечал значительное семантическое разнообразие слова «платформа»: на момент написания им работы (2010 г.) это понятие имело в словарях английского языка 15 различных толкований (которые он свел к четырем семантическим областям), ни одно из которых не охватывало деятельность цифровых посредников, хотя и зависело от всех них ${ }^{4}$.

Любопытны выводы данного автора. Он отмечал, что появление понятия «платформа» - это не нечто органическое (явление, возникающее естественным путем), а результат вполне осознанного использования бизнес-сообществом имеющегося культурного лексикона для определенных целей ${ }^{5}$ именно это, как можно понять его позицию, требует внести ясность в содержание понятия платформа (“То

${ }^{1}$ Cм.: Shelanski H. A. Information, Innovation, and Competition Policy for the Internet // University of Pennsylvania Law Review. 2013. Vol. 161. P. 1675-1676. URL: https://scholarship.law.upenn.edu/cgi/viewcontent.cgi?article $=1025 \&$ context=penn_law_review (дата обращения: 15.12.2020).

2 «The commercial Internet is still a relatively recent phenomenon. The Internet initially became available for private commercial use in 1991 but took several years to become integrated into daily life. Several of the most important digital platforms like Facebook and Twitter are less than ten years old, and even "established" players like Google, Yahoo, and Amazon have not been around for much longer than that» (см.: Shelanski H. A. Op. cit.).

${ }^{3}$ См.: Шваб К. Четвертая промышленная революция. М.: Эксмо, 2016. С. 13.

4 «Like other structural metaphors (think 'network,' 'broadcast,' or 'channel') the term depends on a semantic richness that, though it may go unnoticed by the casual listener or even the speaker, gives the term discursive resonance. I want to begin by highlighting four semantic territories that the word 'platform' has signified in the past, by looking to the Oxford English Dictionary's discussion of the term's etymology. The OED notes 15 different uses, in what I see as four broad categories; the emergence of platform as a descriptive term for digital media intermediaries represents no of these, but depends on all four» (cм.: Gillespie Tarleton. Op. cit.).

5 «A term like 'platform' does not drop from the sky, or emerge in some organic, unfettered way from the public discussion. It is drawn from the available cultural vocabulary by stakeholders with specific aims, and carefully massaged so as to have particular resonance for particular audiences inside of particular discourses. These are efforts not only to sell, convince, persuade, protect, triumph, or condemn, but to make claims about what these technologies are and are not, and what should and should not be expected of them. In other words, they represent an attempt to establish the very criteria by which these technologies will be judged, built directly into the terms by which we know them...» (см.: Gillespie T. Op. cit.). 
call one's online service a 'platform' is not a meaningless claim, nor is it a simple one").

Однако пока все попытки определить сущность цифровой платформы ни в экономических исследованиях ${ }^{1}$, ни в праве к консенсусу не привели, и остается только присоединиться к словам H. A. Shelanski, сказанным в 2013 г., но до сих пор актуальным: "There is no consensus on exactly what constitutes a digital platform" ${ }^{\prime 2}$.

Для того чтобы понять, какой смысл (смыслы) вкладывается в понятие «цифровая платформа», целесообразно посмотреть в первую очередь на экономическую сущность того явления, для описания которого это понятие придумано (как ее видят экономисты), и, соответственно, на имеющиеся в исследованиях определения. Здесь определений различного характера более чем достаточно и на любой вкус. К примеру:

- Жан Тироль рассматривает платформы как модель двусторонних рынков ${ }^{3}$; при этом, как можно понять из его работы, отличительная особенность любой платформы (как рынка) в том, что «продавцы взаимодействуют напрямую с покупателями» ${ }^{4}$; помимо сведения продавцов и покупателей, еще одной важной отличительной особенностью платформы, по мнению Ж. Тироля, является предоставление «технического интерфейса, чтобы взаимодействие между пользователями было для них как можно более удобным» ${ }^{5}$. Специфической особенностью бизнеса платформ, которую он выделял, является ценовая асимметрия: «Платформа обычно устанавливает очень низкие цены на одной стороне рынка и очень высокие на другой» ${ }^{6}$; «платформы часто растут благодаря очень низким ценам на одной стороне рынка, которые привлекают пользователей на этой стороне и косвен-

1 Как отмечено А.Е. Шаститко и Е.Н. Паршиной, «в публикациях по экономике платформ не существует однозначного понимания, какой именно набор признаков экономических обменов дает основание для квалификации их в терминах платформы, а также к каким последствиям выбор того или иного варианта рабочего определения ведет как в аспекте результатов позитивных исследований, так и в аспекте нормативных выводов для экономической политики..» (см.: Шаститко А. Е., Паршина Е. Н. Рынки с двусторонними сетевыми эффектами: спецификация предметной области // Современная конкуренция. 2016. № 1 (55). С. 5-6). Также см.: Яблонский С. А. Многосторонние платформы и рынки: основные подходы, концепции и практики // Российский журнал менеджмента. 2013. № 4. С. 60.

${ }^{2}$ См.: Shelanski H. A. Op. cit. P. 1665.

${ }^{3}$ См.: Тироль Жан. Экономика для общего блага / пер. с франц. И.Е. Шевелевой, науч. ред. перевода М. Левин. М.: Изд-во Ин-та Гайдара, 2020. С. 525.

4 Там же. С. 540.

5 Там же. С. 529.

${ }^{6}$ Там же. С. 543. 
но позволяют платформе получать доходы с другой стороны. Структура цен между двумя сторонами рынка в полной мере использует внешние эффекты (экстерналии), возникающие между ними. Основная идея, - пишет Ж. Тироль, - проста: истинные затраты, понесенные пользователем, не являются прямыми фактическими затратами на их обслуживание. Присутствие пользователя создает выгоду для другой стороны рынка, которую можно монетизировать, что фактически снижает стоимость обслуживания этого пользователя. В некоторых случаях одна сторона рынка может ничего не платить или даже субсидироваться, тогда как другая сторона платит за обе». Понимание Ж. Тиролем платформ - широкое, что можно понять из следующего фрагмента одной из его работ: «...карта VISA и приставка PlayStation, поисковая система Google Chrome, система мгновенного обмена сообщениями WhatsApp и агентство недвижимости, расположенное в непосредственной близости от вас, имеют больше общего, чем вы можете себе представить. Все они являются примерами двусторонних рынков, на которых посредник (VISA, Sony, Google, Facebook, агентство недвижимости) позволяет продавцам и покупателям взаимодействовать... Эти платформы решают двойную проблему контакта между пользователями и предоставления технологического интерфейса, позволяющего им взаимодействовать» ${ }^{2}$;

- А. Моазед и Н. Джонсон дают следующее определение: платформа - это бизнес-модель, «которая позволяет объединить две и более взаимозависимые группы продуктов ради увеличения прибыли всех участников... платформы позволяют потребителям и производителям связываться между собой, чтобы обмениваться товарами, услугами и информацией... платформы сами создают новые рынки» ${ }^{3}$; данные авторы подчеркивают, что платформа как бизнес-модель «ускоряет обмен ценностями... Чтобы этот обмен произошел, платформы собирают вокруг себя крупные, растущие и легкодоступные сети пользователей и ресурсов... создают сообщества и рынки, в рамках которых пользователи взаимодействуют и осуществляют трансакции» 4 ; описывая работу «платформенных бизнес-моделей», они отмечают: «Современные компании и отдельные люди объединяются через сети, а значит, ценность передается непосредственно между ними. В этом и заключается суть механизма работы платформенных бизнес-

${ }^{1}$ Тироль Ж. Указ. соч. С. 531-532.

2 Там же. С. 525.

${ }^{3}$ См.: Моазед А. Платформа: Практическое применение революционной бизнесмодели / пер. с англ. М., 2019. С. 12.

${ }_{4}^{4}$ Там же. С. 37. 
моделей»1; А. Моазед и Н. Джонсон указывают, что любая платформа имеет четыре функции: привлечение аудитории; координация; предоставление инструментов и сервисов; определение правил и стандартов ${ }^{2}$;

- «на самом общем уровне платформы - это цифровые инфраструктуры, которые позволяют двум и более группам взаимодействовать» ${ }^{3}$; давший это определение $H$. Срничек, пишет, что «платформы это новый тип фирмы... они обеспечивают инфраструктуру, выступающую посредником между различными группами пользователей, тяготеют к монопольным форматам за счет сетевых эффектов, используют перекрестное субсидирование ради вовлечения различных групп пользователей и опираются на некоторую базовую архитектуру, определяющую возможности взаимодействия» 4

- К. Шваб, не давая прямого определения платформ, пишет о платформе как «одной из важных моделей деятельности, которая стала возможной за счет сетевых эффектов перехода в цифровой формат»5; довольно важными в его работе являются слова о т. н. «эффекте платформы», «при котором организации, основанные на цифровых технологиях, создают сети, соединяющие продавцов и покупателей широкого ассортимента продукции и услуг, повышая таким образом доходы за счет эффекта масштаба»6; такой эффект «приводит к к концентрации нескольких мощных платформ, доминирующих на своих рынках»7. Любопытно, что этот автор понятие «платформа» применительно к четвертой промышленной революции противопоставляет явлению цифровой платформы третьей промышленной революции ; К. Шваб отмечает эффект снижения издержек: «Цифровые

${ }^{1}$ Моазед А. Указ. соч. С. 34.

2 Там же. С. 49.

${ }^{3}$ См.: Срничек Н. Капитализм платформ / пер. с англ. и науч. ред. М. Добряковой; Нац. исслед. ун-т «Высшая школа экономики». 2-е изд. М.: Изд. дом Высшей школы экономики, 2020. С. 41.

4 Там же. С. 46.

${ }^{5}$ См.: Шваб К. Указ. соч. С. 48.

${ }^{6}$ Шваб К. Указ. соч. С. 15.

7 Там же.

8 «Если во времена третьей промышленной революции возникали сугубо цифровые платформы, то отличительной чертой четвертой промышленной революции является появление глобальных платформ, тесно связанных с физическим миром. Стратегия платформ является одновременно и прибыльной, и дизруптивной. Исследования, проведенные Школой Управления Слоуна Массачусетского Технологического Института, показали, что 14 из 30 крупнейших брендов по суммарной рыночной стоимости в 2013 представляли собой компании, ориентированные на формат платформы» (см.: Шваб К. Указ. соч. С. 48). 
платформы значительно сократили затраты по сделкам и преодолению факторов, препятствующих сделкам, которые возникают у физических и юридических лиц при использовании актива и предоставлении услуги. Каждая сделка теперь может быть разделена на самые мелкие составляющие, предусматривающие экономическую выгоду для всех участвующих сторон. Кроме того, при использовании цифровых платформ предельная себестоимость производства каждого дополнительного продукта, товара или услуги стремится к нулю»1. По мнению К. Шваба, современные платформы «в более широкой перспективе... обеспечивают так называемую “экономику по требованию” (также известную как “экономика совместного потребления”)»²; ния")»²;

- В. Д. Маркова пишет: «Цифровая (технологическая) платформа это модель использования продуктов, услуг или решений на основе комплексного набора компонентов, которая позволяет расширять соответствующие рынки и создавать новые, а также приносит пользователям гораздо больше преимуществ, чем простая сумма составных частей. Такая платформа, как правило, облегчает коммуникации между клиентами и поставщиками»3;

- «цифровая платформа - это система алгоритмизированных взаимовыгодных взаимоотношений значимого количества независимых участников отрасли экономики (или сферы деятельности), осуществляемых в единой информационной среде, приводящая к снижению транзакционных издержек за счёт применения пакета цифровых технологий, работы с данными и изменения системы разделения труда» 4 ;

- «под платформой в общем смысле понимается цифровая среда с набором функций и сервисов, обеспечивающая потребности потребителей и производителей, а также реализующая возможности прямого взаимодействия между ними. Ценность платформы - в предоставлении самой возможности прямой коммуникации и облегчении процедуры взаимодействия участников, что минимизирует количество посредников и улучшает качество и скорость информационного обмена

${ }^{1}$ См.: Шваб К. Указ. соч. С. 21.

${ }^{2}$ См.: Шваб К. Указ. соч. С. 20. O sharing economy также подробнее см.: Calo R. and Rosenblat A. The Taking Economy: Uber, Information, and Power // Columbia Law Review. 2017. Vol. 117. URL: https://ssrn.com/abstract=2929643 (дата обращения: 16.12.2020); Аюшеева И. З. Указ. соч. С. 95-104 и др.

${ }^{3}$ См.: Маркова В.Д. Цифровая экономика: учебник. М.: ИНФРА-М, 2018. С. 59.

${ }^{4}$ Cм.: URL: https://files.data-economy.ru/digital_platforms_project.pdf (дата обращения: 20.09. 2020). 
между действующими лицами. Платформа тем самым снижает трансакционные и прочие издержки ее контрагентов-участников, предоставляет им дополнительную функциональность и способствует созданию инновационных продуктов и решений» ${ }^{\text {; }}$;

- в докладе ОЭСР 2019 г. «An Introduction to Online Platforms and Their Role in the Digital Transformation» ${ }^{2}$ понятие «онлайн-платформа» имеет такое объяснение: «Термин “онлайн-платформа" используется для описания целого ряда услуг, доступных в Интернете, включая рынки, поисковые системы, социальные сети, магазины креативного контента, магазины приложений, коммуникационные услуги, платежные системы, услуги, включающие так называемую "совместную" или "гиг"-экономику, и многое другое... онлайн-платформа определяется как цифровая услуга, облегчающая взаимодействие между двумя или более различными, но взаимозависимыми группами пользователей (будь то фирмы или частные лица), которые взаимодействуют через эту услугу через Интернет»3.

Как хорошо заметно из приведенных определений и объяснений (их, конечно, можно приводить значительно больше), сущность цифровой платформы объясняется исключительно широко (см.: определение Н. Срничека или определение ОЭСР 2019 г.), что позволяет под платформой понимать значительный круг удаленных взаимодействий, либо имеют место попытки свести платформы исключительно к бизнес-модели взаимодействия (обмену товарами и услугами).

Важнейший вопрос, который обсуждается в связи с экономической сущностью платформ, - это сетевой эффект платформ, или эффект платформы.

Такие эффекты разделяют на положительные и отрицательные4, а также прямые и перекрестные (или косвенные) ${ }^{5}$. В самом простом

${ }^{1}$ См.: Цифровые платформы. Методологии. Применение в бизнесе: кол. монография / под общ. ред. Б. Б. Славина, Е. П. Зараменских, Н. Механджиева. М.: Прометей, 2019. С. 17.

${ }^{2}$ Cм.: URL: https://www.oecd-ilibrary.org/science-and-technology/an-introduction-toonline-platforms-and-their-role-in-the-digital-transformation_53e5f593-en (дата обращения: 15.12.2020).

3 «The term "online platform" has been used to describe a range of services available on the Internet including marketplaces, search engines, social media, creative content outlets, app stores, communications services, payment systems, services comprising the so-called "collaborative" or "gig" economy, and much more... an online platform is defined as a digital service that facilitates interactions between two or more distinct but interdependent sets of users (whether firms or individuals) who interact through the service via the Internet».

${ }^{4}$ См.: Баранов В. Н. Сетевые эффекты в Интернете // Транспортное дело России. 2010. № 9. С. 144; Шаститко А.Е., Паршина Е.Н. Указ. соч. С. 6.

${ }^{5}$ См.: Яблонский С.А. Указ. соч. С. 66-68; Шаститко А.Е., Паршина Е.Н. Указ. соч. С. 6 и др. работы. 
виде сетевой эффект может быть определен следующим образом: чем больше пользователей платформы, тем больше возможностей она создает для пользователей; как отмечает С. А. Яблонский, «потребители одной группы (стороны) ценят прямые связи с другими потребителями (прямые сетевые эффекты) или ожидают, что платформы с большим числом пользователей в какой-либо группе... (например, пользователи поисковой платформы, разработчики ПО и др.) предоставляют большее количество и разнообразие дополнительных продуктов и услуг (перекрестные или косвенные сетевые эффекты)...»1.

Другой важнейший вопрос, обсуждаемый в связи с бурным развитием платформ, - это выявленная исследователями тенденция к осуществлению платформой монополистической деятельности, и, соответственно, возможные реакции государства на это, и вопросы антимонопольного регулирования. Соответствующие вопросы активно дискутируются в работах по экономике и праву как за рубежом², так и в России ${ }^{3}$.

Определения цифровой платформы в работах по праву также можно разделить на две большие группы - дающие очень широкое понимание платформы или, напротив, пытающиеся выделить какието специальные признаки, которые объективно сужают круг явлений, под нее попадающих. При этом первых определений гораздо больше. К примеру:

- цифровые платформы определяются «как продукты или услуги, с помощью которых конечные пользователи и широкий спектр до-

${ }^{1}$ См.:Яблонский С.А. Указ. соч. С. 66.

2 Cм.: Shelanski H. A. Op. cit. P. 1663-1705; Hylton K. N. Digital Platforms and Antitrust Law // Boston Univ. School of Law, Law and Economics Research Paper № 19-8, May 2019. URL: https://ssrn.com/abstract=3381803 (дата обращения: 16.12.2020); Robertson V. H. S. E. Antitrust Law and Digital Markets: A Guide to the European Competition Law Experience in the Digital Economy (February 28, 2020). URL: https://ssrn.com/abstract=3631002 (дата обращения: 16.12.2020); Woodcock, Ramsi. The Contrasting Approaches to Power of the Modern State and the Antitrust Laws: Lessons for Platform Regulation (October 3, 2020). URL: https://ssrn.com/abstract=3704450 (дата обращения: 16.12.2020); Hovenkamp H. Antitrust and Platform Monopoly // Yale Law Journal 2021. Vol. 130, U of Penn, Inst for Law \& Econ Research Paper № 20-43. URL: https://ssrn.com/abstract=3639142 (дата обращения: 16.12.2020).

${ }^{3}$ См.: Доценко А.В., Иванов А.Ю. Антимонопольное регулирование, цифровые платформы и инновации: дело Google и выработка подходов к защите конкуренции в цифровой среде // Закон. 2016. № 2. С. 31-45; Вартаев Р.С., Гараев Р.3., Коваленко А.И. Злоупотребление доминированием цифровых платформ (на примере дела Google в России) // Современная конкуренция. 2016. № 5 (59). С. 89-141; Юсупова Г.Ф. ФАС против Google: экономический анализ // Экономическая политика. 2016. № 6. С. 82-9; Касымов Р.Ш. Контроль монополизации в условиях цифровой экономики // Конкурентное право. 2019. № 4. С. 27-30 и др. работы. 
полнительных продуктов, услуг или информации (“приложения") могут взаимодействовать. Таким образом, платформы включают в себя устройства (например, телефоны и планшеты), программное обеспечение (например, операционные системы и браузеры) и услуги (например, поисковые системы, социальные сети и сайты электронной коммерции)»1;

- набор онлайновых цифровых механизмов, алгоритмы которых служат для организации и структурирования экономической и социальной деятельности ${ }^{2}$;

- «при большом разнообразии определений цифровой платформы большинство исследователей рассматривают платформу как цифровую форму организации взаимодействия между поставщиками и потребителями с целью минимизации трансакционных издержек при поиске партнеров, товаров, услуг, организации платежей, заключении контрактов, контроле исполнения договоренностей, оценке репутации отраслевых участников и т. д.»3;

- «под цифровыми платформами принято понимать продукты, с помощью которых осуществляется взаимодействие между потребителями и поставщиками разного рода товаров, услуг и информации. Платформами могут быть как устройства (телефоны, планшеты), так и программные продукты (операционные системы, браузеры) или информационные сервисы (поисковые движки, социальные сети). Функционально цифровые платформы решают две основные задачи: вопервых, играют роль точки входа для потребителей по получению товаров и услуг, выходящих за пределы функциональности самой платформы; во-вторых, предоставляют предпринимателям возможность предложить свои товары и услуги большому числу потребителей»4;

- «анализ различных подходов позволяет определить цифровую платформу как подрывную инновацию, представленную в виде ин-

1 «... For purposes of this Article, I will define digital platforms as products or services through which end users and a wide variety of complementary products, services, or information ('applications') can interact. Platforms therefore include devices (e.g., phones and tablets), software (e.g., operating systems and browsers), and services (e.g., search engines, social networks, and e-commerce sites)» (см.: См.: Shelanski H. A. Op. cit. P. 1665-1666).

${ }^{2}$ См.: «At its simplest, a platform "points to a set of online digital arrangements whose algorithms serve to organize and structure economic and social activity"» (cm.: Katyal S. and Grinvald L. Ch. Platform Law and the Brand Enterprise (January 3, 2018) // Berkeley Technology Law Journal. 2018. Vol. 32; UC Berkeley Public Law Research Paper, Suffolk University Law School Research Paper № 18-20. URL: https://ssrn.com/abstract=3096158 (дата обращения: 16.12.2020).

${ }^{3}$ См.: Стырин Е. М., Дмитриева Н. Е., Синятуллина Л. Х. Указ. соч. С. 35.

${ }^{4}$ См.: Доценко А. В., Иванов А. Ю. Указ. соч. С. 37. 
тегрированной информационной системы, которая обеспечивает многостороннее взаимодействие пользователей, связанное с обменом информацией и ценностями, которые предполагают снижение общих транзакционных издержек, оптимизацию бизнес-процессов, повышение эффективности процесса поставки товаров и услуг» 1 ;

- «в широком смысле цифровая платформа признается “типом технологической архитектуры” программного продукта. Платформы в этом смысле являются основой для более широкого диапазона применения информационных систем, таких как системы планирования, компьютерные операционные системы, интернет-коммуникационные каналы, веб-браузеры, сайты электронной коммерции и социальные медиасайты» ${ }^{2}$;

- «платформы являются физическим воплощением сетевого взаимодействия. Цифровые платформы создают оборудование и программное обеспечение, необходимые для перевода традиционного производства на цифровые рельсы, что позволит снизить производственные издержки и превратить товары в услуги» 3 .

К сожалению, ни одно из указанных определений не является в полной мере правовым - перед нами «переложение» экономических исследований; нет никакого набора признаков (элементов), которые позволили бы ясно отграничить цифровые платформы от иных явлений.

В полной мере этот вывод касается и приводимых в различных работах (как правовых, так и экономических) классификаций платформ. Эти классификации разнообразны, но все их объединяет одно они носят описательный характер и не дают оснований для построения регулирования.

К примеру, можно встретить такую классификацию платформ:

- инструментальные цифровые платформы - в основе находится программный или программно-аппаратный комплекс (продукт), предназначенный для создания программных или программноаппаратных решений прикладного назначения;

- инфраструктурные цифровые платформы - в основе находится экосистема участников рынка информатизации, целью функциониро-

${ }^{1}$ См.: Касымов Р. Ш. Указ. соч. С. 27-30.

${ }^{2}$ См.: Губин Е. П., Харитонова Ю. С. Цифровые платформы в Европе, Китае и России: основные подходы и тенденции правового регулирования // Право и экономика. 2020. № 8 (340). С. 6.

${ }^{3}$ См.: Кашкин С.Ю., Алтухов А.В. В поисках концепции правового регулирования искусственного интеллекта: платформенные правовые модели // Вестник Университета имени О.Е. Кутафина. 2020. № 4 (68). С. 29. 
вания которой является ускоренный вывод на рынок и предоставление потребителям в секторах экономики решений по автоматизации их деятельности (ИТ-сервисов), использующих сквозные цифровые технологии работы с данными и доступ к источникам данных, реализованные в инфраструктуре данной экосистемы;

- прикладные цифровые платформы - бизнес-модель по предоставлению возможности алгоритмизированного обмена определёнными ценностями между значительным числом независимых участников рынка путём проведения транзакций в единой информационной среде, приводящая к снижению транзакционных издержек за счёт применения цифровых технологий и изменения системы разделения труда ${ }^{1}$.

В одной из презентаций (ПАО «Ростелеком» ${ }^{2}$ ) все эти уровни выстроены в определенную иерархию, где в основе первый вид указанных платформ - с логикой «от основного программного продукта к продукту, создающему рынок».

H. Срничек дает несколько иное понимание существующих платформ (указывая при этом, что в одной платформе может переплетаться несколько видов):

- рекламные платформы: извлекают информацию о пользователях, выполняют хитроумные задачи по ее анализу и по результатам продают рекламное пространство;

- облачные: владеют оборудованием и программным обеспечением для компаний, чья деятельность связана с цифровой сферой, и предлагают их в аренду;

- промышленные: создают оборудование и программное обеспечение, необходимое для перевода традиционного производства на интернет-рельсы, что позволит снизить производственные издержки и превратить товары в услуги;

- продуктовые: генерируют доходы, используя другие платформы и с их помощью трансформируя традиционный товар в услугу и собирая ренту или абонентскую плату;

- бережливые: стараются минимизировать объем активов, находящихся у них в собственности, и выигрывать за счет максимального сокращения издержек ${ }^{3}$.

${ }^{1}$ Cм.: URL: https://files.data-economy.ru/digital_platforms_project.pdf (дата обращения: 20.09.2020). Также cм.: URL: https://www.econ.msu.ru/sys/raw.php?o=46781\&p =attachment (дата обращения: 20.09.2020).

2 См.: URL: https://files.data-economy.ru/digital_platforms.pdf (дата обращения: 20.09.2020).

${ }^{3}$ См.: Срничек Н. Указ. соч. С. 47. 
Весьма любопытные классификации (типологии) цифровых платформ содержит материал ОЭСР 2019 г. («An Introduction to Online Platforms and Their Role in the Digital Transformation» ${ }^{1}$ ).

И, тем не менее, подчеркнем: пока никакого практического (для целей регулирования) эффекта большинство из названных (как и многие иные классификации) классификаций не имеет.

Между тем на современном этапе и на перспективу это главная задача - не просто понять, какие виды цифровых платформ существуют (и, кстати, возможно, эти классификации сильно изменились бы, если бы ответили на главный вопрос: что есть платформа и что не является платформой), понять, как с позиций регулирования подходить к различным платформам.

\section{Заключение}

Что показывает проведенный анализ развития отечественного права в части цифровых платформ, определений платформ, разграничения платформ от иных сходных явлений, рассмотрение их многочисленных классификаций?

Сложность в определении платформы, отсутствие разграничения между платформой и «не платформой», отсутствие юридически значимых классификаций платформ ставят вопрос: вправе ли мы сегодня столь вольно использовать это понятие в различного рода стратегических, концептуальных документах и нормативных актах? Нам представляется, что ответ на этот вопрос отрицательный.

Между тем, как только вопросы платформ перешли из задачи их описания в программах, концепциях, стратегиях в плоскость формулирования конкретных правовых решений, немедленно встал вопрос о том, как регулировать. В самом первом приближении этот вопрос встал в антимонопольной повестке. Уже понятно, что платформа как явление, экономический феномен ведет к перераспределению рыночной власти, позволяет незаметно монополизировать отдельные сферы. Такие тенденции связаны с ролью платформ в экономике. Как пишет Ж. Тироль, «почти бесконечное количество источников информации и ограниченное время, которым мы располагаем для их обработки, помещают посредников и платформы, которые помогают нам найти партнеров, в центр экономического процесса» ${ }^{2}$. При этом исследова-

${ }^{1}$ Cм.: URL: https://www.oecd-ilibrary.org/science-and-technology/an-introduction-toonline-platforms-and-their-role-in-the-digital-transformation_53e5f593-en (дата обращения: 15.12.2020).

${ }^{2}$ См.: Тироль Ж. Указ. соч. С. 527. 
тели отмечают, что платформы «возводят обширную инфраструктуру, тратя изрядные суммы на покупку других компаний, и инвестируют в собственные производственные мощности. Они владеют не только информацией - они становятся владельцами инфраструктуры общества. А значит при любом анализе эффекта этих платформ на экономику следует принимать во внимание их монополистические тенденции» ${ }^{1}$.

Но как построить регулирование? Какие средства (методы) регулирования применять, если неясно, как данное явление отличается от других? Как описать новые явления и «привязать» возможности антимонопольного органа, созданные для иной эпохи (индустриальной), которые дает антимонопольное законодательство? Или установить новые правовые средства? Учитывая, что речь идет о т. н. «сетевом эффекте», который создают платформы («чем больше пользователей у платформы, тем более ценной она становится для всех остальных» ${ }^{2}$ ), при описании экономических понятий правовым языком получается текст, содержащий огромное количество неопределенностей, экономического новояза и усмотрения регулирующего органа, что, конечно же, недопустимо.

Наступил период, когда мы должны дать описание платформы в праве. Подчеркнем, дело не только в необходимости выдержать чистоту юридической терминологии (что важно само по себе). Это критично для принятия адекватных, релевантных правовых решений (в том числе, кстати, и в части того, на каком уровне регулировать те или иные новые отношения), отделения платформы от остальных экономических и юридических феноменов.

Антимонопольная повестка - это только первый слой, важный, но далеко не единственный.

Во всех сферах общественной жизни в самом ближайшем будущем в структуру отношений (взаимодействий субъектов социальной реальности) будет встроена «инфраструктура» - платформа. Понятно, что тогда огромное количество правоотношений будет включать взаимодействие с использованием такой «инфраструктуры». То есть участие платформы в правоотношениях будет носить массовый характер, притом в тех случаях, в которых ранее его использование не то что не предполагалось, а даже не мыслилось. В отдельных работах можно встретить упоминание о «платформах правосудия», «платформизации правосудия», появлении «платформенного права» или

\footnotetext{
${ }^{1}$ См.: Срничек Н. Указ. соч. С. 83.

${ }^{2}$ Там же. C. 43.
} 
«права платформ», электронных помощников судьи для вынесения приговоров и проч. ${ }^{1}$

Говоря иначе, в правоотношениях незримо возникнет кто-то третий, который будет предоставлять сервис для взаимодействия сторон, видеть результаты этого взаимодействия, личные и иные данные участников, иметь возможность агрегировать их разным образом и т. д.

H. Срничек справедливо пишет, что «предоставляя людям цифровое пространство для взаимодействия, платформы оказываются в положении, позволяющем им извлекать данные из анализа природных процессов..., производственных процессов..., а также из наблюдения за действиями других компаний и пользователей...»². Это, очевидно, должно привести к секуляризации (причем установленной на уровне правовых норм, а не «по факту») платформ для обмена «чувствительной» информацией. К примеру, сложно представить, что государство «упустит» контроль за платформой, с помощью которой будет (в перспективе) осуществляться правосудие.

Глобально это ставит вопрос о равенстве, поскольку через какоето время остро встанет вопрос доступности услуги (продукта): если лицо не будет иметь возможности обращаться к той или иной платформе, то это приведет либо к невозможности их получения, либо существенному снижению возможностей․․ Еще один глобальный вызов

${ }^{1}$ См.: Булгакова Е. В., Денисов И. С., Булгаков В. Г. Киберправосудие // Администратор суда. 2018. № 4. С. 13-16; Мажорина М. В. Цифровые платформы и международное частное право, или Есть ли будущее у киберправа? // Lex russica. 2019. № 2. C. 107-120; Она же. Мировая экономика цифровых платформ: поиск новых регуляторных моделей // Правовое регулирование цифровой экономики в современных условиях развития высокотехнологичного бизнеса в национальном и глобальном контексте: монография / под общ. ред. В.Н. Синюкова, М.А. Егоровой; Московский государственный юридический университет имени О.Е. Кутафина (МГЮА). М.: Проспект, 2019. С. 31-34; Рагимов И. М.оглы, Аликперов Х.Д.-оглы. «Электронные весы правосудия» (цели, возможности, преимущества) // Уголовное судопроизводство. 2019. № 3. С. 8-14; Кондюрина Ю. А. Принципы цивилистического процесса в системе электронного правосудия: дис. ... канд. юрид. наук. Саратов, 2020. С. 56; Харитонова Ю.С. Платформизация правосудия: опыт Китая и будущее судебных систем мира // Вестник арбитражной практики. 2020. № 3. С. 3-11 и ряд др. работ.

${ }^{2}$ См.: Срничек Н. Указ. соч. С. 46-47.

3 Хорошо об этом написано в Решении ФАС России по делу № 11/01/10-41/2019 по делу «Booking.com» в части гостиничного бизнеса: «средству размещения (имеется 8 виду гостиница - прим. А.Г.) необходимо быть представленным на платформах (сайтах) агрегаторов, популярных среди пользователей сети «Интернет» всего мира, особенно если на платформе агрегатора также размещаются конкурирующие средства размещения, а также, если средство размещения не обладает широкой известностью или популярной торговой маркой (брендом). В противном случае, средство размещения рискует потерять потребителей в пользу конкурирующих средств размещения, размещающихся на платформах (сайтах) агрегаторов» (см.: URL:https://br.fas.gov.ru/ca/upravlenie-po- 
для государства - это диссонанс между частным характером отдельных платформ (ими могут владеть частные лица) и тем влиянием, которое эти платформы приобретают для публичной жизни (и здесь, повторимся, разговор не только об антимонопольной повестке). «Отключение» конкретного лица от доступа к платформе может иметь для него негативные последствия; эту проблему право должно «видеть» и иметь арсенал необходимых решений, основанный на балансе интересов.

Платформа - это модель экономической деятельности, исключающая множество институтов, к которым привыкли экономические агенты (в части сбыта, рекламы и проч.), а значит, перед нами в полный рост проблема высвобождения большого числа квалифицированных кадров: они скоро поймут, что в их услугах и знаниях работодатели будущего просто не нуждаются.

Но дальше - больше. То, что мы называем «платформа», - это модель удаленного взаимодействия, своего рода сеть контрактов, которые завязаны на эту платформу, совокупность которых может по существу заменять прежние институты, в которых ранее люди мыслили свое взаимодействие. «Офис», «организация», «юридическое лицо» (как организация) и проч. - все эти привычные формы взаимодействия людей, «сцепки» прав и обязанностей будут подвергаться риску. Типичные представления о труде, трудовом распорядке, гарантиях и прочих результатах достижений борьбы профсоюзов с работодателями за права трудящихся также будут уходить в прошлое; будут расти временные (гибкие) и негарантированные формы занятости ${ }^{1}$ и самозанятости ${ }^{2}$ - то, что на языке несколько подзабытой политэкономии называется эксплуатацией. В социальной сфере перед нами встанет проблема, которую философы и социологи называют увеличением численности новой социальной общности

kontrolyu-za-gosudarstvennymi-i-munitsipalnymi-informatsionnymi-sistemami/cdf15018-ef 29-40e8-acbd-d39edc8aee39/?query=booking.com (дата обращения - 09.02.2021).

${ }^{1}$ Как отмечает Ж. T. Тощенко, «работодатель стремится максимально уменьшить риск потерять свое место и свой доход. Поэтому наряду с технической и технологической перестройкой производства, совершенствованием управления, правовым приспособлением к требованиям рынка самый быстрый приспособляемый резерв он видит в гибком использовании рабочей силы, что достигается уменьшением постоянно занятых работников и увеличением тех, которых можно держать на “поводке" путем временности работы и привлекаемых кадров» (см.: Тощенко Ж. Т. Прекариат: от протокласса к новому классу / Институт социологии ФСНИСЦ РАН; РГГУ. М.: Наука, 2018. С. 255).

${ }^{2}$ См.: Тироль Ж. Указ. соч. С. 572-582. 
(слоя, класса и проч.) - «прекариата» ${ }^{1}$. Результатом этого может стать еще более существенная дифференциация, а то и вовсе поляризация общества.

Иногда можно услышать мнение, что цифровая экономика поможет победить бедность; отчасти это связывают и с появлением платформ. Объяснение этому дается весьма тривиальное: у большего количества людей будет доступ к значительному числу возможностей, платформы позволят создать почти безграничные опции для реализации отдельным человеком, где бы он ни находился (при условии доступа в сеть), своего потенциала и «продажи» способностей. На моей памяти случай, когда подобного рода лозунг пытались даже включить в концептуальные документы по развитию цифровой экономики. Между тем даже общего взгляда на платформы (не касаясь иных аспектов цифровой экономики) достаточно, чтобы высказать сомнение в такой постановке вопроса: сами по себе новые возможности можно приветствовать, но результат может быть обратный: бедность не только не будет преодолена - существует как раз риск углубления этой проблемы за счет монополизации, эксплуатации, перехода ее в хроническое состояние на фоне резкой поляризации доходов. Такого рода риски необходимо не просто осмыслить и описать в документах стратегического характера; возможно, они требуют нетривиальных решений ${ }^{2}$.

Платформы - это изменение экономических отношений собственности; в отдельных работах это отмечается в форме перехода om владения к доступу ${ }^{3}$. Изменение отношений собственности - это очень

${ }^{1}$ См.: Стэндинг Гай. Прекариат: новый опасный класс. М.: Ад Маргинем Пресс, 2014. 328 с.; Тощенко Ж. Т. Указ. соч.

${ }^{2}$ Как отмечает К. Шваб, «растущее неравенство и обеспокоенность существующей несправедливостью представляют собой значительную проблему... Концентрация преимуществ и ценностей в руках небольшого процента людей... усугубляется так называемым эффектом платформы... Для предотвращения концентрации ценностей и власти в руках ограниченного числа лиц необходимо найти способ сбалансировать преимущества и риски цифровых платформ (включая промышленные платформы) за счет обеспечения открытости и возможностей для коллективной инновации...» (см.: Шваб К. Указ. соч. С. 15).

${ }^{3}$ «...Zero waste and the resurrection of dead capital can be achieved because of a shift from a consumption culture that is dominated by acquisition to a mindset of access. Instead of owning a car, what becomes important is the ability to use one when needed. Instead of purchasing the lawnmower, knowing that it is there to serve you when the grass has grown is sufficient. In particular, as population density and urbanization continue to rise, congestion and smaller spaces push consumers to prefer access above ownership. This shift from ownership to access further reduces transaction costs by reducing the stakes of the deal. Purchasing an annual membership in a car sharing platform is not as weighty a deal as buying a car, and purchasing use of a car for an hour is not as costly as renting a car for a day...» (cM.: Lobel, Orly. 
серьезный вызов для права; здесь речь может идти вовсе не о точечных изменениях, а об изменениях парадигмального характера.

Еще один аспект - это дефрагментация правового регулирования, вторжение платформенного права в «святая святых» государства монополию на создание (в том числе санкционирование) нормы права; сюда же относятся вопросы создания многочисленных квазиюрисдикционных органов по разрешению споров и т. д. 1

К решению этих - стратегических - вопросов, которые порождаются платформизацией всего и вся, мы еще не только не приступали, но даже не находимся на стадии концептуального характера постановки проблем.

\section{Библиографический список}

1. Алексеев P.А., Абрамов А.В. Проблемы и перспективы применения электронного голосования и технологии избирательного блокчейна в России и за рубежом // Гражданин. Выборы. Власть. 2020. № 1(15). С. 9-21.

2. Алексеенко А.П. Регулирование деятельности электронных платформ по Закону КНР «Об электронной коммерции»// Юрист. 2020. № 7. С. 62-68.

3. Аналитический доклад «Конкуренция на финансовом рынке». Подготовлен Банком России при участии ФАС России к XXVII Международному финансовому конгрессу (6-8 июня 2018 г., г.СанктПетербург). 88 с. URL: http://www.cbr.ru/statichtml/file/41186/20180 607_report.pdf.

4. Аюшеева И.З. Гражданско-правовые сообщества в условиях экономики совместного потребления // Актуальные проблемы российского права. 2020. Т. 15, № 6. С. 95-104.

5. Баранов В.Н. Сетевые эффекты в Интернете // Транспортное дело России. 2010. № 9. С. 144-146.

6. Боровик А.И. Компонентно-ориентированная программная платформа для автономных необитаемых подводных аппаратов: дис. ... канд. техн. наук. Владивосток, 2018. 177 с.

7. Булгакова Е.В., Денисов И.С., Булгаков В.Г. Киберправосудие // Администратор суда. 2018. № 4. С. 13-16.

8. Бурдина E.B. Цифровизация судебной деятельности: направления, прогнозы и риски // Администратор суда. 2020. № 2. С. 10-14.

The Law of the Platform // Minnesota Law Review, 2016; San Diego Legal Studies Paper № 16-212. URL: https://ssrn.com/abstract=2742380 (дата обращения: 20.12.2020).

${ }^{1}$ См.: Габов А.В. Правовое регулирование краудфандинга в России... С. 28-29. 
9. Вартаев Р.С., Гараев Р.З., Коваленко А.И. Злоупотребление доминированием цифровых платформ (на примере дела Google в России) // Современная конкуренция. 2016. №5 (59). С. 89-141.

10. Габов А.В. Изменения в праве как следствие развития цифровой экономики // Пермский юридический альманах. 2020. № 3. С. 39-48.

11. Габов А.В., Хаванова И.А. Краудфандинг: законодательное оформление web-модели финансирования в контексте правовой доктрины и зарубежного опыта // Вестник Пермского университета. Юридические науки. 2020. Вып. 47. С. 28-44.

12. Габов А.В. Правовое регулирование краудфандинга в России: учеб. пособие. Белгород: ИД «БелГУ» НИУ «БелГУ», 2020. 348 с.

13. Грешняков П.И. Повышение энергетической эффективности мехатронной системы управления движением робота-тренажёра вождения на базе платформы Стюарта с многопозиционным цифровым управлением электропневматическими следящими приводами на дискретных клапанах: дис. ... канд. техн. наук. Самара, 2019. 193 с.

14. Губин Е.П., Харитонова Ю.С. Цифровые платформы в Европе, Китае и России: основные подходы и тенденции правового регулирования // Право и экономика. 2020. № 8 (340). С. 5-13.

15. Доценко А.В., Иванов А.Ю. Антимонопольное регулирование, цифровые платформы и инновации: дело Google и выработка подходов к защите конкуренции в цифровой среде // Закон. 2016. № 2. C. 31-45.

16. Желтоножко T.A. Методы и инструменты управления разработкой и реализацией инновационных направлений промышленной политики, основанных на применении технологических платформ: дис. ... д-ра экон. наук. М., 2016. 23 с.

17. Злывко O.A. Разработка механизма реализации инвестиционных проектов на основе государственно-частного партнерства посредством технологических платформ: автореф. дис. ... канд. экон. наук. М., 2015. 22 с.

18. Информационное право и становление основ гражданского общества в России. Материалы теоретического семинара по информационному праву 2007 г. / под ред. И.Л. Бачило. М.: Институт государства и права РАН, 2008. 277 с.

19. Информационное общество и социальное государство: сб. науч. работ. М.: Институт государства и права РАН; ИПО «У Никитских ворот», 2011. 248 c.

20. Попов Л.Л., Мигачев Ю.И., Тихомиров С.В. Информационное право: учебник / М.: Норма: Инфра-М, 2010. 496 с. 
21. Капустин О.A. Приоритетные направления организации судебной деятельности на современном этапе // Администратор суда. 2020. № 2. С. 3-9.

22. Карцхия А.М. Цифровые технологические (онлайн) платформы: российский и зарубежный опыт регулирования // Гражданское право. 2019. № 3. С. 25-28.

23. Карихия А.А. Гражданско-правовая модель регулирования цифровых технологий: дис. ... д-ра юрид. наук. М., 2019. 394 с.

24. Касымов Р.Ш. Контроль монополизации в условиях цифровой экономики // Конкурентное право. 2019. № 4. С. 27-30.

25. Кашкин С.Ю., Алтухов А.В. В поисках концепции правового регулирования искусственного интеллекта: платформенные правовые модели // Вестник Университета имени О. Е. Кутафина. 2020. № 4 (68). C. 26-40.

26. Классен Р.К. Консервативные СУБД класса BIGDATA с регулярным планом обработки запросов на кластерной платформе: автореф. дис. ... канд. техн. наук. Казань, 2019. 26 с.

27. Кленов А.И. Динамический синтез и анализ механизма, реализующего движение локомоционной мобильной платформы в жидкости: дис. ... канд. техн. наук. Ижевск, 2019.137 с.

28. Комментарий к Уставу железных дорог СССР / под ред. Г.Б. Астановского. М.: Юридическая литература, 1986. 400 с.

29. Кондюрина Ю.А. Принципы цивилистического процесса в системе электронного правосудия: дисс. ... канд. юрид. наук. Саратов, 2020. 197 c.

30. Коржавина А.C. Методы и алгоритмы модулярной арифметики для массовой обработки сверхдлинных чисел на гибридных вычислительных платформах: автореф. дис. ... канд. техн. наук. Пенза, 2019. 23 c.

31. Кузнецов П. У. Феномены и правовые фикции цифровой сферы // Российское право: образование, практика, наука. 2019. № 6. С. 72-81.

32. Мажорина М.В. Цифровые платформы и международное частное право, или Есть ли будущее у киберправа? // Lex russica. 2019. № 2. C. 107-120.

33. Мажорина М.В. Мировая экономика цифровых платформ: поиск новых регуляторных моделей // Правовое регулирование цифровой экономики в современных условиях развития высокотехнологичного бизнеса в национальном и глобальном контексте: монография / под общ. ред. В.Н. Синюкова, М.А. Егоровой; Московский государственный юридический университет имени О.Е. Кутафина (МГЮА). М.: Проспект, 2019. С. 19-34. 
34. Мардер Н.С. О терминологии в законодательстве об информационных технологиях // Понятийный аппарат в информационном праве: кол. монография / отв. ред. И.Л. Бачило, Т.А. Полякова, В.Б. Наумов. М.: ИГП РАН; Изд-во «Канон+»; РООИ «Реабилитация», 2017. C. 255-262.

35. Маркова В.Д. Цифровая экономика: учебник. М.: ИНФРА-М, 2018. $186 \mathrm{c}$.

36. Моазед А. Платформа: Практическое применение революционной бизнес-модели / пер. с англ. М., 2019. 288 с.

37. Поляков Р.Ю. Мобильная приборная платформа для системы экологического мониторинга загрязнения токсичными газами атмосферного воздуха: дис. ... канд. техн. наук. Курск, 2019. 165 с.

38. Право цифровой администрации в России и во Франции. Сборник научных материалов Российско-французской международной конференции. 27-28 февраля 2013 года. М.: Институт государства и права РАН; Изд-во «Канон+»; РООИ «Реабилитация», 2014. 178 с.

39. Пролетарская B.A. Метод выполнения запросов к хранилищу данных на платформе распределённой параллельной обработки данных: дис. ... канд. техн. наук. М., 2020.143 с.

40. Пыстогов С В. СУБД полнообъектных картографических сцен с ассоциативной защитой на кластерной платформе: дис. ... канд. техн. наук. Казань, 2019. 144 с.

41. Рагимов И.М.-оглы, Аликперов Х.Д.-оглы. «Электронные весы правосудия» (цели, возможности, преимущества) // Уголовное судопроизводство. 2019. № 3. С. 8-14.

42. Семилетов С.И. Правовые проблемы организации электронного оборота документов в государственном управлении // Теоретические проблемы информационного права. М.: Институт государства и права РАН, 2006. С. 160-174.

43. Сорокин А.П. Методы разработки модулей аппаратных вычислительных платформ для обработки сложноструктурируемых изображений: дисс. ... канд. технических наук. М., 2018. 169 с.

44. Срничек Н. Капитализм платформ / пер. с англ. и науч. ред. М. Добряковой; Нац. исслед. ун-т «Высшая школа экономики». 2-е изд. М.: Изд. дом Высшей школы экономики, 2020. 128 с.

45. Стэндинг Г. Прекариат: новый опасный класс. М.: Ад Маргинем Пресс, 2014. 328 с.

46. Стырин Е.М., Дмитриева Н.Е., Синятуллина Л.Х. Государственные цифровые платформы: от концепта к реализации // Вопросы государственного и муниципального управления. 2019. № 4. С. 31-60. 
47. Теоретические проблемы информационного права. М.: Институт государства и права РАН, 2006. 291 с.

48. Тироль Ж. Экономика для общего блага / пер. с франц. И.Е. Шевелевой, науч. ред. перевода М. Левин. М.: Изд-во Ин-та Гайдаpa, 2020. 696 c.

49. Тощенко Ж.Т. Прекариат: от протокласса к новому классу / Инт социологии ФСНИСЦ РАН; РГГУ. М.: Наука, 2018. 350 с.

50. Условия реализации прав граждан и организаций на основе информационных технологий. М.: Ин-т государства и права РАН; ИПО «У Никитских ворот», 2010. 248 с.

51. Федоров В.И. Проекты по автоматизации голосования в исторической ретроспективе // Гражданин. Выборы. Власть. 2020. № 1(15). C. 34-55.

52. Харитонова Ю.С. Платформизация правосудия: опыт Китая и будущее судебных систем мира // Вестник арбитражной практики. 2020. № 3. С. 3-11.

53. Цифровые платформы. Методологии. Применение в бизнесе: колл. монография / под общ. ред. Б.Б.Славина, Е.П. Зараменских, Н. Механджиева. М.: Прометей, 2019. 228 с.

54. Цифровая экономика: проблемы правового регулирования: монография / отв. ред. В В. Зайцев, О.А. Серова. М.: КНОРУС, 2019. 200 с.

55. Шаститко А.Е., Паршина Е.Н. Рынки с двусторонними сетевыми эффектами: спецификация предметной области // Современная конкуренция. 2016. № 1 (55). С. 5-18.

56. Шваб К. Четвертая промышленная революция. М.: Эксмо, 2016. $138 \mathrm{c}$.

57. Юсупова Г.Ф. ФАС против Google: экономический анализ // Экономическая политика. 2016. № 6. С. 82-99.

58. Яблонский C.A. Многосторонние платформы и рынки: основные подходы, концепции и практики // Российский журнал менеджмента. 2013. № 4. C. 57-78.

59. Calo R. and Rosenblat A. The Taking Economy: Uber, Information, and Power. Columbia Law Review. 2017. Vol. 117. URL: https://ssrn. com/abstract= 2929643 (дата обращения: 15.12.2020).

60. Gillespie T. The Politics of "Platforms" // New Media \& Society. 2010. Vol. 12. Issue 3. URL: https://www.researchgate.net/publication/258173728_The_politics_of_'platforms' (дата обращения: 15.12.2020).

61. Hovenkamp H. Antitrust and Platform Monopoly // Yale Law Journal. 2021. Vol. 130. U of Penn, Inst for Law \& Econ Research Paper № 20-43. URL: https://ssrn.com/abstract=3639142 (дата обращения: 16.12.2020). 
62. Hylton K.N. Digital Platforms and Antitrust Law // Law and Economics Research Paper. May 2019. № 19-8 / Boston University School of Law. URL: https://ssrn.com/abstract=3381803 (дата обращения: 16.12.2020).

63. Evans D.S., Hagiu A., Schmalensee R. Invisible Engines: How Software Platforms Drive Innovation and Transform Industries. The MIT Press, 2006.

64. Katyal S. and Grinvald L. Ch. Platform Law and the Brand Enterprise // Berkeley Technology Law Journal. 2018. Vol. 32; UC Berkeley Public Law Research Paper, Suffolk University Law School Research Paper № 18-20. URL: https://ssrn.com/abstract=3096158 (дата обращения: 15.12.2020).

65. Lobel O. The Law of the Platform // Minnesota Law Review. 2016. March 4. San Diego Legal Studies Paper № 16-212. URL: https://ssrn.com/ abstract=2742380 (дата обращения: 20.12.2020).

66. Robertson V H. S. E. Antitrust Law and Digital Markets: A Guide to the European Competition Law Experience in the Digital Economy (February 28, 2020). URL: https://ssrn.com/abstract=3631002 (дата обращения: 15.12.2020).

67. Rochet J.-C., Tirole J. Platform Competition in Two-Sided Markets // Journal of European Economic Association. 2003. № 1 (4). P. 990-1029. URL: https://www.rchss.sinica.edu.tw/cibs/pdf/RochetTirole3.pdf (дата обращения: 16.12.2020).

68. Shelanski H.A. Information, Innovation, and Competition Policy for the Internet // University of Pennsylvania Law Review. 2013. Vol. 161. P. 1663-1705. URL: https://scholarship.law.upenn.edu/cgi/viewcontent. cgi?article=1025\&context=penn_law_review (дата обращения: 15.12.2020).

69. Woodcock R. The Contrasting Approaches to Power of the Modern State and the Antitrust Laws: Lessons for Platform Regulation (October 3, 2020). URL: https://ssrn.com/abstract $=3704450$ (дата обращения: 16.12.2020). 